\title{
LIGHT MICROSCOPIC LOCALIZATION OF BRAIN OPIATE RECEPTORS: A GENERAL AUTORADIOGRAPHIC METHOD WHICH PRESERVES TISSUE QUALITY ${ }^{1}$
}

\author{
MILES HERKENHAM* AND CANDACE B. PERT $\ddagger$ \\ ${ }^{*}$ Laboratory of Neurophysiology and $\ddagger$ Chief, Section on Brain Biochemistry, The Neuroscience Branch, National Institute of \\ Mental Health, Bethesda, Maryland 20205
}

Received October 5, 1981; Revised March 15, 1982; Accepted March 22, 1982

\begin{abstract}
A general technique is described for using slide-mounted unfixed tissue sections to characterize and visualize drug and neurotransmitter receptors in brain or other tissues. The preparation of material, from fresh frozen, unfixed brain to dried sections securely attached to slides, is described in detail. The tissue can be kept intact during incubation at varying temperatures in solutions containing radiolabeled ligand, ions, buffers, and allosteric effectors. Strategies are described for determining optimal stereospecific binding with highest signal-to-noise ratios and for determining that a "meaningful" receptor is being studied. Dry formaldehyde fixation by vapors from heated paraformaldehyde preserves the tissue quality and traps the ligand near its site on the receptor, permitting subsequent histological processing through alcohols, solvents, and aqueous media, including liquid nuclear track emulsion.

Visualization of $\left[{ }^{3} \mathrm{H}\right]$ naloxone- or $\left[{ }^{3} \mathrm{H}\right]$ enkephalin-labeled opiate receptor distributions in rat and human brains is achieved by tritium-sensitive film or by classical "wet" emulsion autoradiography. The advantages of the film include its ease of use and the ability to quantify receptor density by densitometry which can be computer-assisted. The advantage of the emulsion is the greater resolution and the concomitant appearance of morphology in cell-stained sections. Examples of correlations of opiate receptor distributions with underlying cytoarchitecture illustrate the potential for receptor localization studies.
\end{abstract}

A major thrust of recent neuroscientific research has been to assign neurochemical content to known neuronal pathways. To the extent that a given neurotransmitter or drug receptor represents the postsynaptic locus where a given neurosecretion acts, a method for visualizing patterns of receptor distribution would aid these efforts. However, a major obstacle to routine autoradiographic localization of drug and neurotransmitter receptors has been that too often only reversible ligands are available for radiolabeling. Early methods for visualizing drug and neurotransmitter receptors (Kuhar and Yamamura, 1975; Pert et al., 1975) were modeled after the techniques for visualizing steroid receptors (Plaff, 1968; Stumpf, 1968) and featured in vivo injection of large quantities of radiolabeled ligand, a brief survival period to optimize the signal-to-noise ratio, and the use of "dry" autoradiographic methods which avoid aqueous media capable of removing noncovalently bound ligand (Stumpf and Roth, 1966). The disadvantages of this in vivo approach are

\footnotetext{
' We acknowledge Dr. Peter Munson for statistical consultation.
}

many; large quantities of radiolabeled ligand are required, comparisons of adjacent sections incubated with different ligands or under different incubation conditions cannot be performed, and perhaps most importantly, a large amount of nonspecific binding unrelated to receptor localizations cannot be removed.

An improved alternative is modeled after the method of receptor binding in tissue homogenates in test tubes, but instead, binding is performed on tissue sections attached to glass slides (Polz-Tejera et al., 1975). The advantages of the in vitro approach, including its potential for studying human brain receptors, have been emphasized by Young and Kuhar (1979). These include the ability $(i)$ to characterize binding kinetics and structureactivity relationships on slide-mounted tissue sections and (ii) then to use identically prepared sections for receptor visualization, (iii) to localize receptors for substances like peptides which are metabolized rapidly in vivo or fail to cross the blood-brain barrier, (iv) to study the effects of manipulating binding conditions (e.g., ligand concentrations, ions, temperature, nucleotides, etc.), $(v)$ to wash the sections to achieve low nonspecific 
binding, and finally, (vi) to mark several neurochemical aspects simultaneously or in adjacent sections (Young and Kuhar, 1979; Herkenham and Pert, 1981).

Preserved tissue morphology permits accurate descriptions of the cellular components of brain structures where the receptor resides and thus can reveal important associations (e.g., absence of a given cell type in human pathological tissues). However, most current fixation methods use aldehyde perfusion to maintain tissue quality, a procedure which often reduces receptor binding or alters its allosteric properties. In this paper, we describe in detail the preparation of cryostat-cut, unfixed tissue sections which remain securely affixed to slides even during incubation in aqueous media at physiological temperatures while maintaining tissue quality that compares favorably with that obtained from aldehyde-perfused animals.

A simple strategy for optimizing receptor binding and demonstrating the specificity of binding is described. The study of biologically irrelevant, artifactual binding sites (Hollenberg and Cuatecasas, 1976) can be avoided by seeking close correlations between ligand analogue binding displacement potencies and their independently established biological or behavioral potencies (Pert and Herkenham, 1981). Putative specific radiolabeled ligand binding on sections can be characterized by liquid scintillation spectrophotometry prior to visualization by autoradiography. Further quantification with attention to spatial location can be obtained by quantifying autoradiographic image densities on tritium-sensitive film (Penney et al., 1981). However, localization of autoradiographic grains relative to underlying tissue morphology is best achieved with the use of liquid nuclear track emulsion (Rogers, 1979). We present evidence that exposure to hot formaldehyde vapors fixes many receptorassociated radiolabeled ligands and permits receptor localization by liquid emulsion autoradiography in morphologically preserved tissue.

\section{Materials and Methods}

\section{Brain removal}

Small animals are decapitated without anesthesia. Larger animals are anesthetized, with attention paid to the anesthetic effects on the receptor in question. A small brain is immersed into isopentane at $-30^{\circ} \mathrm{C}$ which serves to freeze it in its normal shape, but the brain should be transferred within $30 \mathrm{sec}$ to crushed dry ice to prevent expansion and/or cracking of some part of it. Larger brains can be made firm by immersion into ice cold saline for 5 to $10 \mathrm{~min}$ before being placed onto a hollowed out bed of sifted dry ice and covered. They may be blocked to manageable size by cutting while frozen on a band saw. Blocked or whole brains are secured to cryostat pedestals with embedding matrix (Lipshaw M-1). They are stored in airtight bags at $-15^{\circ} \mathrm{C}$.

\section{Cutting of sections}

Reliable adherence of the section to the slide and subsequent high quality staining characteristics can be obtained by the following procedure. The temperature of the cryostat is set according to desired section thickness.
Sections $25 \mu \mathrm{m}$ thick cut optimally at $-14^{\circ} \mathrm{C}$. Thinner sections can be cut at colder temperatures (Rogers, 1979). Sections are placed or pressed onto a cold gelatin-coated slide (Hendrickson and Edwards, 1978; Rogers, 1979). Several sections may be positioned on a slide before attachment by melting (Fig. 1). A finger or warm bar moved slowly across the back of the slide produces a controlled wave of melting. Since refreezing at this stage should be avoided, the slides are transferred to a slide box is filled, it is transferred to a chamber which is both cold $\left(0^{\circ}\right.$ to $\left.-10^{\circ} \mathrm{C}\right)$ and free of humidity. A sealed desiccator jar containing desiccant and kept in an ice/salt cold $\left(0^{\circ}\right.$ to $\left.-15^{\circ} \mathrm{C}\right)$ and free of humidity. A sealed desiccator jar containing desiccant and kept in an ice/salt mixture or freezer, or a drying box lined with desiccant and kept in a closed cryostat, will allow the sections to dry at subzero temperatures without freezing. The sections must be kept out of air currents which will cause them to freeze before drying. Drying time is $2 \mathrm{hr}$ or longer. A partial vacuum will accelerate drying.

A section that has dried at or below $0^{\circ} \mathrm{C}$ without refreezing has a glassy, transparent appearance. Sections that have dried frozen will appear frosty white, while sections that have dried at warmer temperatures will appear translucent; both types may disintegrate during subsequent incubation and washing. The glassy, clear tissue sections, however, remain securely attached to the slides even during incubations at physiological temperatures and in nonisotonic solutions. After drying, the slide boxes, which are covered and sealed in a bag containing desiccant, can be stored indefinitely in a freezer at $-15^{\circ} \mathrm{C}$.

\section{Receptor binding on slide-mounted sections: Studying a "meaningful" phenomenon}

Generally, it is our experience that binding phenomena observed in homogenates appear even more robust with these unfixed slide-mounted sections (e.g., Bowen et al., 1981). Slides are placed in pairs into small beakers or slide mailers containing the various choices of incubation contents. After incubation, washing, and drying, the scraped-off section or slide fragment containing it is placed into a scintillation vial and assessed for radioactivity by liquid scintillation spectrophotometry.

Assessing nonspecific binding. To assess the proportion of the total binding that is nonspecific, competing unlabeled ligand is added initially in about 10,000 -fold excess of the concentration of the labeled ligand. Subsequently, the lowest concentrations of displacer which give maximal inhibition of binding can be used for "blank" conditions. Tests with enantiomers will demonstrate stereospecificity of binding (e.g., Goldstein et al., 1971; Pert and Snyder, 1973). In our experience, at least $50 \%$ specific binding is necessary for adequate receptor visualization.

Ligand concentration. Since nonspecific binding generally increases linearly as a function of radiolabeled ligand concentration, while specific binding reaches an asymptote as receptors are saturated, a fairly low (below $K_{d}$ ) tritiated ligand concentration usually yields the highest ratio of total-to-nonspecific binding. Since binding at these low concentrations, however, can require lengthy exposure times to visualize autoradiographically, saturat- 


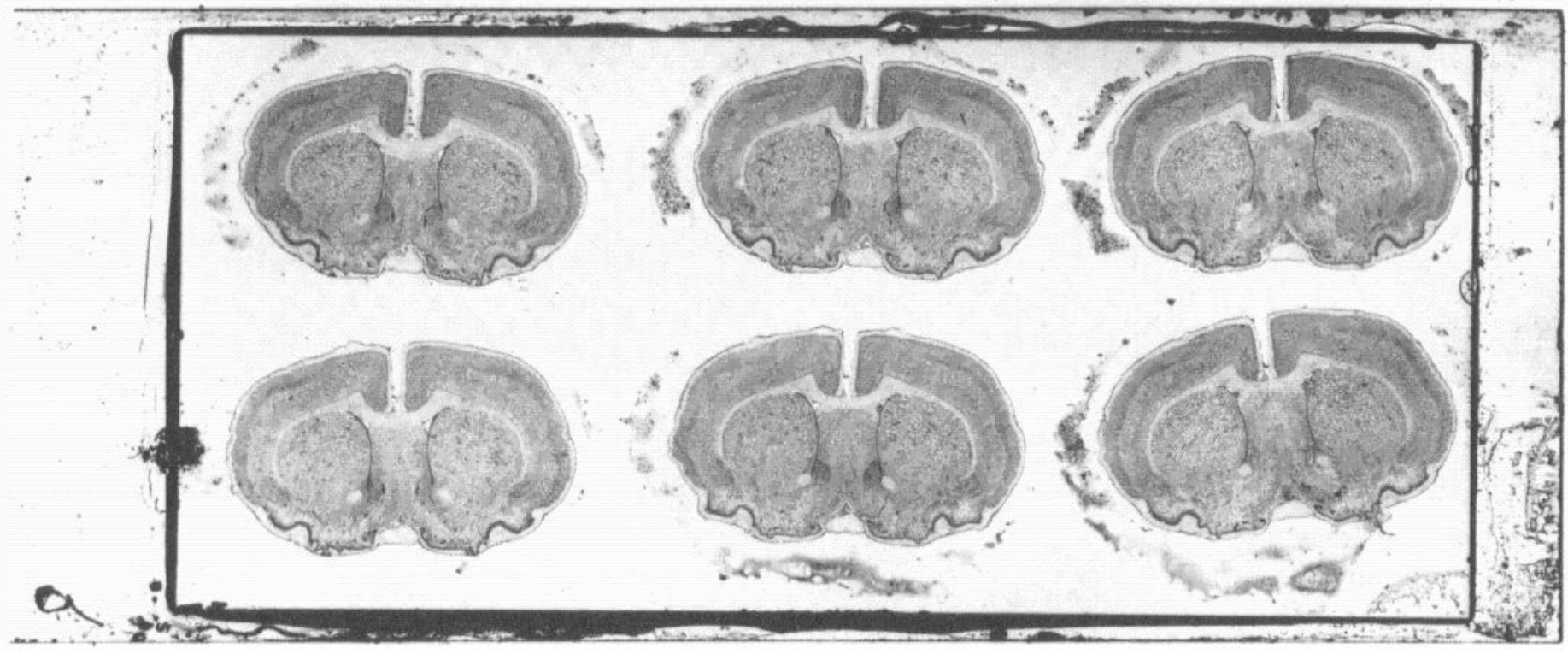

Figure 1. Photograph of a $\left[{ }^{3} \mathrm{H}\right]$ naloxone-labeled, thionin-stained slide with attached coverslip. The 25- $\mu \mathrm{m}$-thick sections were prepared as described under "Materials and Methods." Four sections were cut and positioned onto four separate slides, four more were cut and discarded and then the next four serial sections were applied, until the four slides each had six sections. They then were melted as described. Four series of adjacent sections through the entire brain were generated. After incubation, emulsion coating, and 14 weeks exposure, striatal opiate receptor patches are visible as dark spots on the equally spaced (200- $\mu \mathrm{m}$ separation) sections. The cytoarchitectural details of cortex, striatum, and basal forebrain are clearly visible even at this magnification $(\times$ 3.5).

ing ${ }^{3} \mathrm{H}$-ligand concentrations are useful to employ. Still, low concentrations may be required for selective labeling of a higher affinity binding site of two putative receptor subłypes, although additional nonkinetic differentiating characteristics would need to be demonstrated.

Temperature, ions, and incubation time. Some very profound effects of ions are often detectable only at appropriate temperatures (e.g., Creese et al., 1975; Costa et al., 1979). The tissue should always be incubated and washed in a neutral buffered solution, and isotonicity is helpful for maintaining tissue quality, particularly at warmer temperatures. Sucrose often may be used as a noninterfering ingredient to achieve isotonicity. Fragile tissues may benefit from the inclusion of bovine serum albumin $(0.2$ to $1 \%)$ and/or protease inhibitors, which also protect peptide ligands.

Total and nonspecific binding can be counted at various incubation durations. For visualizing receptor distributions, the length of the incubation should be determined by the optimal signal-to-noise ratio rather than by attempts to achieve "steady state" conditions.

Preincubation. The beneficial effects of preincubation in buffer, which can double the amount of specific binding, often are attributed to the removal of competing endogenous ligands from the tissue (Pasternak et al., 1975). No less important is the fact that preincubation in various ionic media can couple or uncouple receptors from other membrane components and thus stabilize their ligand selectivity pattern in the most desirable form for the particular ligand and receptor subtype under study (Bowen et al., 1981). In any case, optimization of the preincubation conditions should proceed empirically: temperature, ionic content, and length of preincubation should be varied in a systematic manner.

Washing at the termination of the incubation. High affinity specific receptor binding generally dissociates at a temperature-dependent rate. By contrast, nonspecific binding is not temperature dependent and is eliminated most effectively by the largest possible number of successive immersions into ice cold (nonradioactive) buffers in the least amount of time. Generally, we have found that it is sufficient to pass slide-filled racks through three to six $400-\mathrm{ml}$ washes to achieve lowest nonspecific binding. Sodium is included in the washing medium if it does not promote the dissociation of the receptor. ligand complex. For $\left[{ }^{3} \mathrm{H}\right]$ naloxone, the half-life of dissociation under the conditions that we use is about $0.5 \mathrm{hr}$ (Pert and Snyder, 1973); therefore, six washes in ice cold phosphate-buffered saline spanning 2 min eliminates nearly all of the nonspecific binding and only about $4 \%$ of the specific binding. Enkephalin-incubated sections are washed in ice cold Tris- $\mathrm{HCl}$ buffer, $\mathrm{pH} \mathrm{7.4,} \mathrm{at} 0^{\circ} \mathrm{C}$ for the same duration. Binding that has a high dissociation rate even at low temperatures requires more rapid washing, at the risk of losing the necessary specific binding for receptor visualization.

Drying at the termination of the incubation. Tissue on the slides should be dried as quickly and completely as possible, since diffusion of reversibly bound ligand can occur. Room temperature air from a hair dryer or air hose is used at sufficient strength to blow the bulk of the water off within a few seconds and complete the drying process within a few minutes.

Validation of optimized binding conditions. After an 
TABLE I

Comparison of ligand selectivity patterns for opiate receptors from different sources

For the 10 analogues of morphine tested for binding potency on brain slices prepared as described under "Materials and Methods," the values are directly proportional and nearly perfectly correlated ${ }^{a}$ with both pharmacological activity in the guinea pig ileum (Creese and Snyder, 1975) and binding potencies in brain homogenates (Pert and Garland, 1978). It has been shown previously that the correlation between pharmacological activity and binding in the guinea pig intestine is excellent $(p<0.001$; Creese and Snyder, 1975) and that the ligand selectivity pattern of the intestinal receptor is indistinguishable $(p<0.005)$ from the displacement of $\left[{ }^{3} \mathrm{H}\right]$ naloxone from brain membranes and the ability to produce "analgesia" in the mouse hot plate test (Wilson et al., 1975).

\begin{tabular}{|c|c|c|c|}
\hline Opiate & $\begin{array}{l}\mathrm{ID}_{50} \text { of }\left[{ }^{3} \mathrm{H}\right] \text { Naloxone Displacement } \\
\text { from Slide-mounted Brain Slices }\end{array}$ & $\begin{array}{l}\mathrm{ED}_{50} \text { of Suppression of Muscular Con- } \\
\text { traction in Guinea Pig Ileum }\end{array}$ & $\begin{array}{l}\mathrm{ID}_{(x)} \text { of }\left[{ }^{-3} \mathrm{H}\right] \text { Naloxone Displacement } \\
\text { from Brain Membrane }\end{array}$ \\
\hline & \multicolumn{3}{|c|}{$n M$} \\
\hline Etorphine & 0.2 & 0.25 & 0.6 \\
\hline Levallorphan & 3.0 & 2.9 & 2 \\
\hline Levorphanol & 10 & 30 & 15 \\
\hline Methadone & 100 & 80 & 200 \\
\hline D-(Ala $\left.{ }^{2}\right)$-Met-enkephalin & 500 & $600^{\circ}$ & $400^{f}$ \\
\hline Morphine & 100 & 200 & 100 \\
\hline Propoxyphene (Darvon) & 1,000 & 2,000 & 12,000 \\
\hline Codeine & 10,000 & 15,000 & 10,000 \\
\hline Dextrallorphan & 10,000 & 2,800 & $7,000^{\mu}$ \\
\hline Dextrorphanol & 10,000 & 8,500 & $8,000^{\mu}$ \\
\hline
\end{tabular}

"The data were logged to achieve a more normal distribution; " $y$ on $x$ " and " $x$ on $y$ " regression analyses were performed comparing binding on slides with intestinal pharmacological potency and binding on slides with binding to homogenates. None of the values were significantly different from $1(p<0.01)$; the structural regression slopes (Munson and Rodbard, 1981) were 1.05 from slices versus intestinal potency and 0.98 for slices versus homogenates and $r=0.985$ for the intestinal comparison and 0.97 for the homogenate comparison.

${ }^{b}$ Herkenham and Pert, 1980.

${ }^{c}$ Creese and Snyder, 1975.

${ }^{d}$ Pert and Garland, 1978.

' Lord et al., 1977.

'Pert et al., 1976b.

${ }^{2}$ Pert and Snyder, 1973.

optimized putative signal-to-noise ratio has been achieved, evidence must be produced that a "meaningful receptor," rather than an artifactual binding site, is under study. Kinetic studies are useful and can be compared with the kinetics of binding to tissue homogenates (Young and Kuhar, 1979, 1980; Meibach et al., 1980; Penney et al., 1981). More compelling evidence is the displacement potency of a series of ligand analogues (Pert and Herkenham, 1981). It is not uncommon to have superb correlations between the ability of a series of analogues to displace the binding of the radiolabeled ligand and their ability to elicit selective behavioral or physiological effects (Table I). While binding to talc or other nonbiological substances can mimic receptor binding if kinetics alone are considered (Hollenberg and Cuatrecasas, 1976), to our knowledge, no nonbiological substance has ever mimicked a receptor in tests showing precise correlation between potencies of ligands which displace binding and elicit physiological or behavioral effects.

Opiate receptor binding. In our laboratories, we have labeled and visualized receptors for a number of peptides and synthetic analogues, including receptors for opiate alkaloids and peptides, benzodiazepines, spiperone, neurotensin, muscimol, and phencyclidine. However, most of our efforts to date have been directed at visualizing opiate receptor binding, and toward this end, we have employed numerous alkaloid and peptide ligands. In the present report, specific $\left[{ }^{3} \mathrm{H}\right]$ naloxone and $\mathrm{D}$-Ala-D-Leu$\left[{ }^{3} \mathrm{H}\right]$ enkephalin binding are illustrated. No preincubation was used. Incubations were in $(i) 10^{-9} \mathrm{M}\left[{ }^{3} \mathrm{H}\right]$ naloxone (specific activity, $50 \mathrm{Ci} / \mathrm{mmol}$ ) for $60 \mathrm{~min}$ at $4^{\circ} \mathrm{C}$ in 0.05

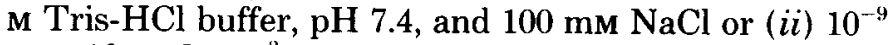
M D-Ala-D-Leu- $\left[{ }^{3} \mathrm{H}\right]$ enkephalin (specific activity, $25 \mathrm{Ci}$ / $\mathrm{mmol}$ ) for $30 \mathrm{~min}$ at $23^{\circ} \mathrm{C}$ in the same Tris buffer containing $100 \mathrm{~mm} \mathrm{NaCl}, 2 \mu \mathrm{M} \mathrm{GTP}$, and $3 \mathrm{~mm}$ manganese acetate.

\section{Autoradiographic visualization of receptors}

Fixation. The ligand-receptor complex must be kept intact during subsequent histological procedures involving aqueous media. Fixation by postincubation immersion of sections into liquid fixatives appears unable to fix the ligand at most receptors and tends to cause chemography (M. Herkenham and C. B. Pert, unpublished observations). However, dry formaldehyde fixation by vapors of paraformaldehyde powder at $80^{\circ} \mathrm{C}$ is extremely effective. The incubated sections first must be dried thoroughly. The racks of slides then are placed into a desiccator jar at the bottom of which is a Petri dish containing 10 to $30 \mathrm{gm}$ of paraformaldehyde powder. The powder should be equilibrated to room humidity (30 to $60 \%)$ by leaving it exposed to room air for at least 1 day. Reduced pressure from a vacuum pump sufficient to maintain a seal between the lid and the jar is applied, and the jar is heated in an oven at $80^{\circ} \mathrm{C}$ for $2 \mathrm{hr}$. Under these conditions, formaldehyde vapors will fix the sections without condensing on them or altering their appearance in any way. The jar should be opened under a hood and racks must be removed immediately to prevent the cooling vapor from condensing on the slides. The 
powder can be reused indefinitely. The sections are left in a drafted hood overnight to rid them of residual vapors prior to processing for autoradiography by coating with emulsion. For the method of apposition to tritium-sensitive film, fixation is not required but permits the tissue quality to be maintained for subsequent emulsion analysis and/or staining. In either case, the formaldehyde vapors produce no chemographic artifact on the film or emulsion.

Autoradiography. Slide-mounted sections to be apposed to tritium-sensitive film (LKB Ultrofilm ${ }^{3} \mathrm{H}$, Gaithersburg, MD or Kodak XAR-2, Rochester, NY) are placed into standard $x$-ray cassettes (we use Wolf) and the film is placed over them in total darkness. The cassettes are kept at room temperature or colder for periods of 2 to 16 weeks before developing.

The procedure for emulsion coating follows standard procedures previously described for autoradiographic tracing of axonal connections in the central nervous system (Cowan et al., 1972). To insure tight adherence of the emulsion to the section, to improve staining characteristics, and to remove any unfixed, diffusible radiolabeled ligand, we routinely demyelinate (defat) our sections through aqueous alcohol and xylene (Hendrickson and Edwards, 1978; Kent et al., 1981) before coating them with the emulsion.

In the darkroom, under safelight conditions at $80 \%$ humidity, sections are dipped into Kodak NTB-2 emulsion in a water bath at $38^{\circ} \mathrm{C}$. The emulsion has been melted, diluted $1: 1$ in a filtered, distilled water solution containing $0.01 \%$ Dreft detergent, and carefully but thoroughly stirred. The individually dipped sections are placed vertically to dry slowly. After $2 \mathrm{hr}$ of drying, they are placed into light-tight boxes containing desiccant capsules, sealed, and stored in a freezer at $-15^{\circ} \mathrm{C}$ for periods of weeks to months before developing.

The development of both LKB film and Kodak emulsion can be done under safelight conditions with Kodak D-19 developer and Kodak Rapid Fix. We develop the film for $4 \mathrm{~min}$ at $20^{\circ} \mathrm{C}$ and the emulsion for $2 \mathrm{~min}$ at $17^{\circ} \mathrm{C}$. The developed slides are washed and stained according to standard histological techniques (Hendrickson and Edwards, 1978). The developed film can be viewed directly or analyzed by a densitometer. Slides are examined with a microscope under bright-field and dark-field illumination.

\section{Results}

Autoradiography of $\left[{ }^{3} \mathrm{H}\right]$ naloxone binding with tritium-sensitive film. While use of tritium-sensitive film (Larsson and Ullberg, 1977) does not permit simultaneous visualization of receptor grains and underlying morphology, it has three distinct advantages: it is simple to use, it does not require successful fixation of the ligand-receptor complex, and the image can be easily quantified by densitometry. Figure 2 shows LKB film autoradiographs of $\left[{ }^{3} \mathrm{H}\right]$ naloxone binding in selected coronal rat brain sections exposed for 8 weeks to a single sheet of film. The cassette had been filled with 30 slides, each containing three sections. A partial mapping of opiate receptor distributions throughout the brain and spinal cord is provided in this single illustration. Detailed comparisons of congruencies between receptor distribution and underlying brain structure gleaned from celland fiber-stained preparations of the same sections are possible (Herkenham, 1981; Herkenham et al., 1981, Lewis et al., 1981; Wise and Herkenham, 1982). However, the quality of the sections is so uniformly good that even these tritium images, taken at roughly $1-\mathrm{mm}$ intervals through the brain, can be correlated with previously published opiate receptor maps (Pert et al., 1976a; Atweh and Kuhar, $1977 \mathrm{a}, \mathrm{b}, \mathrm{c}$ ) and with structures shown in the atlas of König and Klippel (1963), whose plane of section matches that shown in Figure 2 (the corresponding levels are given in the legend to Fig. 2).

The film autoradiographs can be useful in other valuable ways: they can be analyzed for quantitative densitometry (Palacios et al., 1981a; Penney et al., 1981; Rainbow et al., 1982; Unnerstall et al., 1982) and they do not alter the section that they overlie. These two features allow us to test the adequacy of the fixation procedure in maintaining the receptor-ligand complex throughout the subsequent processing required for emulsion autoradiography. In one test, two adjacent sections were incubated, washed, and dried together. Both were fixed in formaldehyde vapors for $2 \mathrm{hr}$ at $80^{\circ} \mathrm{C}$, but one was processed further through a series of alcohols, xylenes, and water according to the defatting procedure. The two sections were placed side by side in a cassette and exposed to the film. The appearance and density of labeling in each was the same (data not shown). In another test, a complete series of rat brain sections was exposed to film before fixation and then exposed again after the fixation, defatting, and rehydrating steps. The two sets of film autoradiographs then were compared by computerized densitometry (Goochee et al., 1980; Quirion et al., 1981) to examine the possibility that the label might have been redistributed if fixation were inadequate. Figure 3 shows the computer image of one of the sections from the film, the area analyzed for densitometry, and the two density plots. The striking concordance of the two plots, which was typical of all levels of rat brain, argues against any selective loss or redistribution of label.

Analogous experiments demonstrating varying degrees of loss, but no redistribution of vapor-fixed radiolabels (dihydromorphine, D-Ala-D-Leu-enkephalin, and ethylketocyclazocine), were performed. Only dihydromorphine was lost in any significant amount, and this loss was greatly reduced by raising the temperature of fixation to $95^{\circ} \mathrm{C}$ (data not shown).

The major value of the tritium-sensitive film approach is that quantification can be obtained by densitometry. The values of mean optical density \pm SEM within any circumscribed area, obtained by computer-assisted densitometry (Goochee et al., 1980), range 30- to 40-fold from most optically dense areas, like the habenular streak, to the most transparent, like the corpus callosum (Table II). Analysis of whole striatum, striatal patches, and "between patch" areas at several levels reveals that there is a definite rostral-to-caudal gradient in total opiate receptor density, even though opiate receptor-rich patches are equally dense throughout the striatum. Sev- 

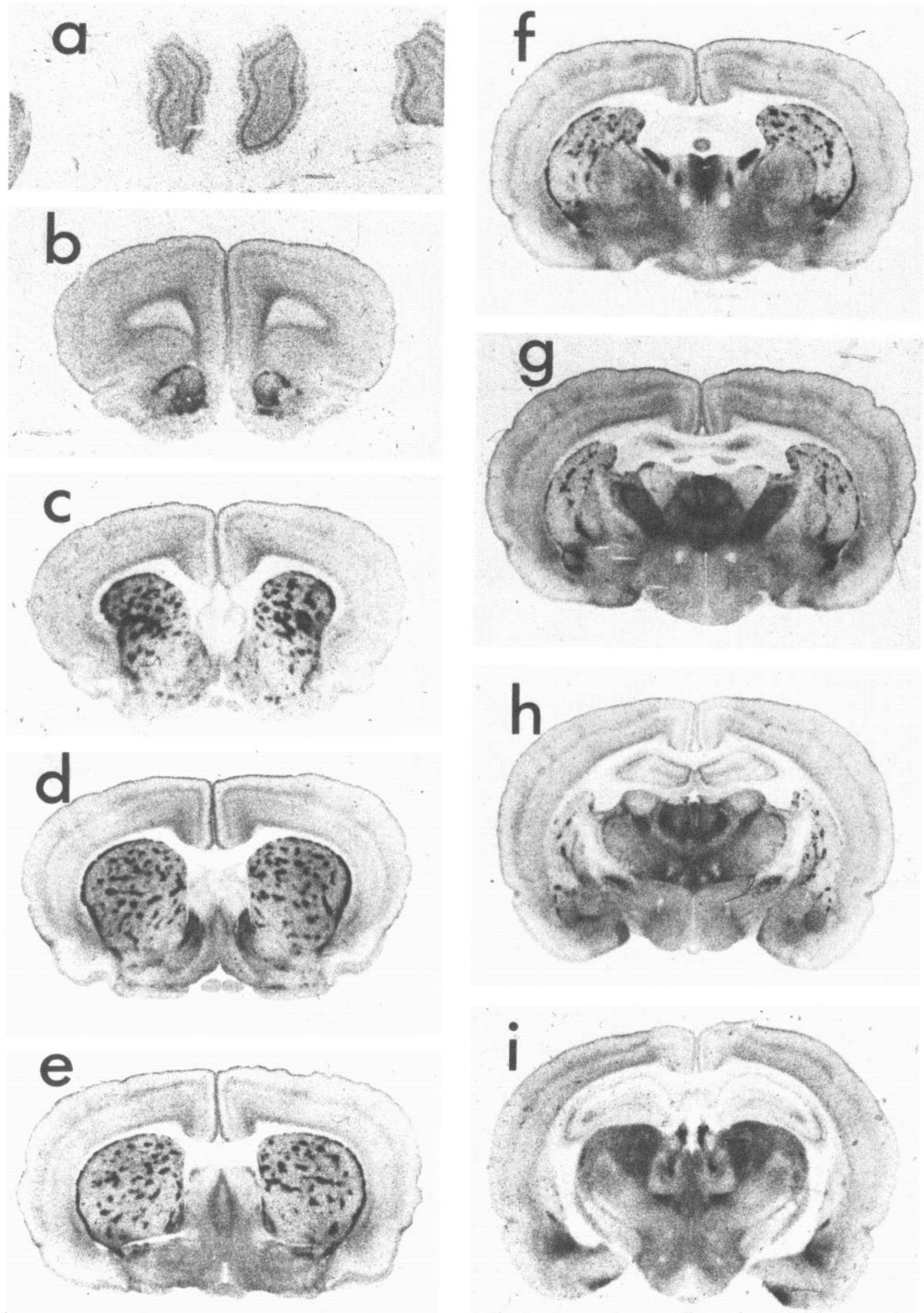

Figure 2. Rat brain series prepared as described in Figure 1 but exposed to LKB Ultrofilm after incubation, drying, fixing, and defatting. The sections had been incubated together in $\left[{ }^{3} \mathrm{H}\right]$ naloxone and exposed to a single sheet of film for 8 weeks. In this fashion, quantitative densitometric comparisons between sections are possible, though they should not be made on the basis of these photographs, which were printed individually to optimize the appearance of receptors at each level. Sections were cut in the 

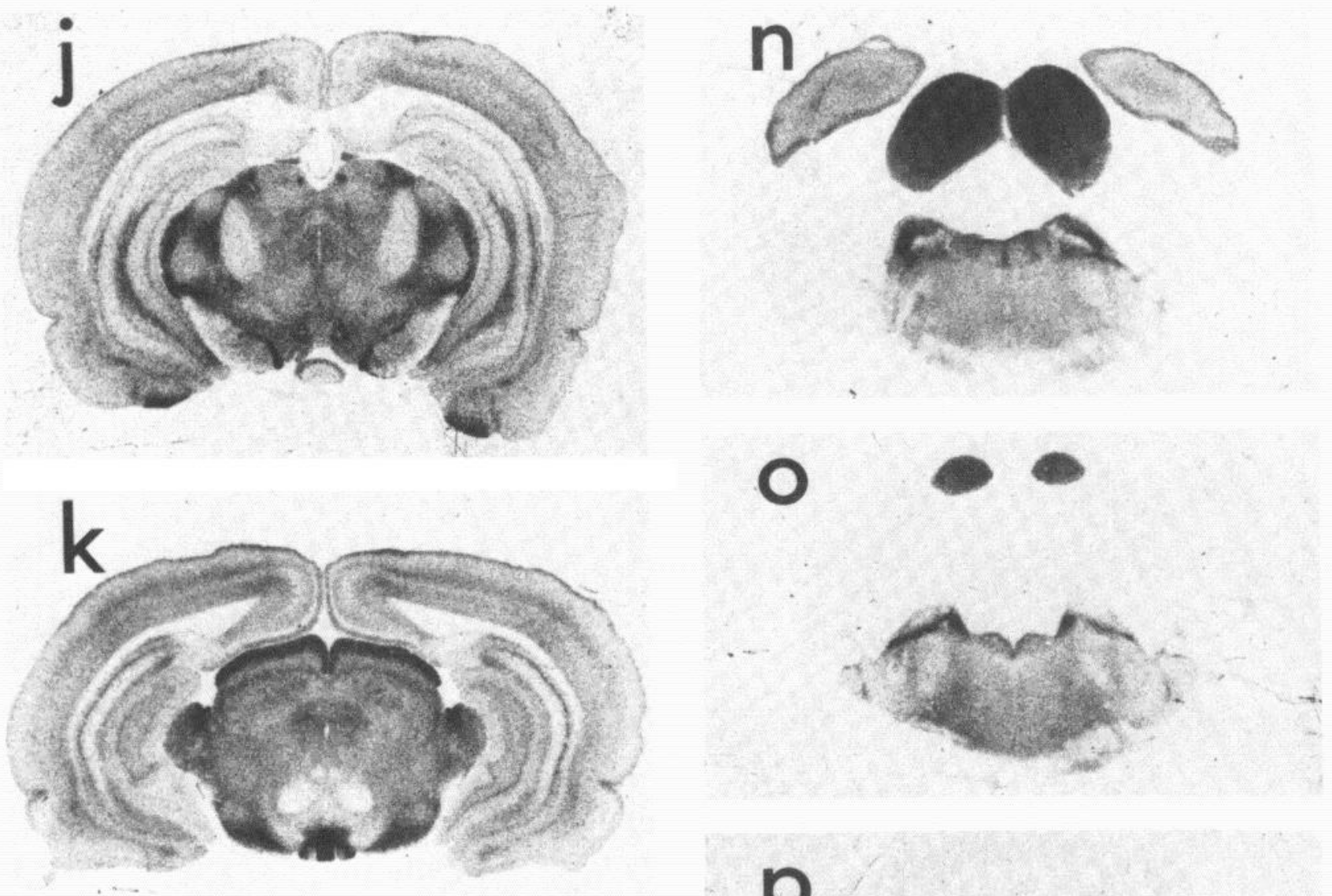

\section{p}
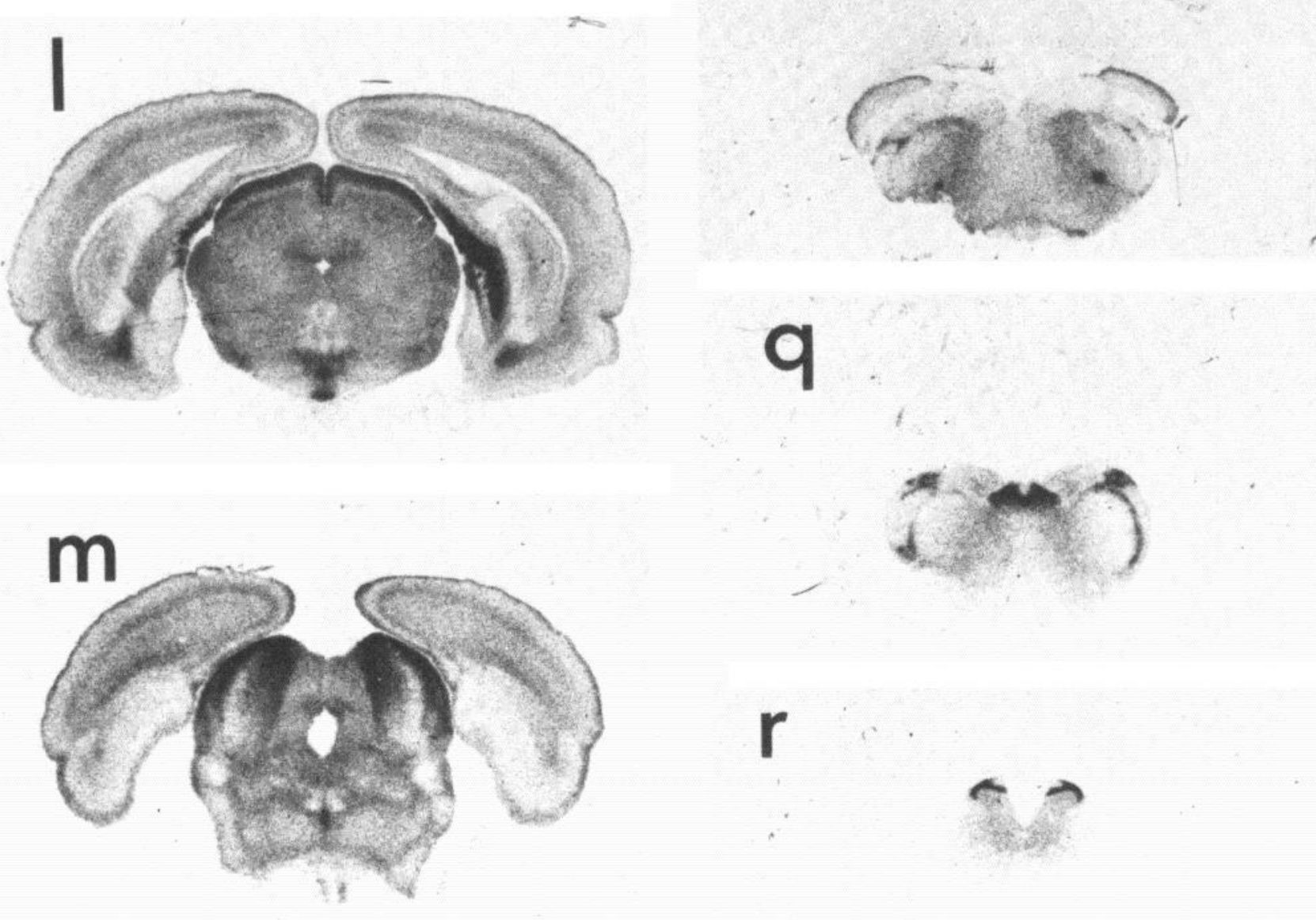

plane of König and Klippel (1963); the levels from that atlas are as follows: $b, \mathrm{~A} 10050 \mu ; c, \mathrm{~A} 9650 \mu ; d, \mathrm{~A} 8620 \mu ; e, \mathrm{~A} 7470 \mu ; f, \mathrm{~A} 6280 \mu$; $g, \mathrm{~A} 5340 \mu ; h, \mathrm{~A} 4620 \mu ; i, \mathrm{~A} 3430 \mu ; j, \mathrm{~A} 2420 \mu ; k, \mathrm{~A} 1610 \mu ; l, \mathrm{~A} 620 \mu$; and $m, \mathrm{P} 290 \mu$. Levels not listed in the atlas of König and Klippel are $a$, the olfactory bulb, and $n$ to $r$, which are brainstem and cervical spinal levels. Listed according to distance from the interaural line (Zeman and Innes, 1963; Pellegrino and Cushman, 1967), they are (approximately): $n,-1.6 \mathrm{~mm} ; o,-2.2 \mathrm{~mm} ; p$, $-3.8 \mathrm{~mm}$; and $q,-5.0 \mathrm{~mm}$. Magnification $\times 5$. 

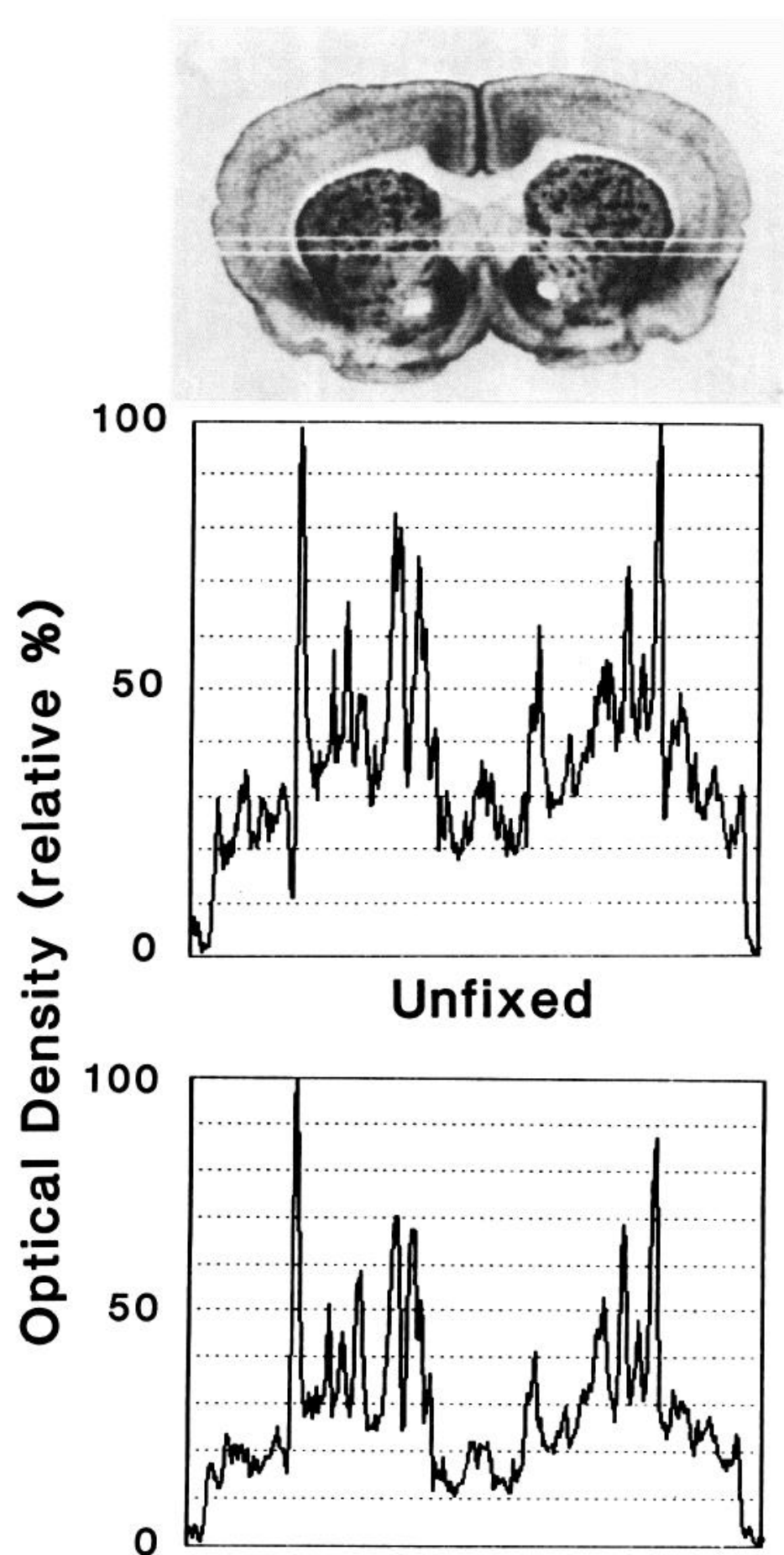

Fixed and Defatted

eral of the most opiate receptor-rich brain areas have been listed and quantified in Table II.

Liquid emulsion autoradiography of $\left[{ }^{3} \mathrm{H}\right]$ naloxone binding. The method of tissue preparation, treatment, and fixation described in this paper permits high resolution light microscopic analysis of receptor localizations. Cell infrastructure is preserved and visible in a Nissl strain so that detailed morphometric and cytoarchitectural analyses are possible. Since an emulsion layer is applied wet, the surface of the section is blanketed
Figure 3. Computer-analyzed densitometry of film image showing $\left[{ }^{3} \mathrm{H}\right]$ naloxone binding to rat striatum and cortex after three weeks exposure at room temperature to LKB Ultrofilm. The upper panel is a photograph taken of the density image on a television screen. The details of the hardware (scanning densitometer, computer, disk storage system, image display system, color monitors, joy stick controls, and line printer) and programming are given in Goochee et al. (1980). The same section was analyzed before and after the histological steps of vapor fixation and defatting in alcohols, xylenes, and water. The density plots were taken as mean optical density through the horizontal column marked by the parallel white bars in the section at the top. Density is expressed as the relative percentage of density within that particular column. Subtle variability between the density plots is due to the inability to relocate the column to be measured exactly in separate films by means of the joy stick controls. evenly, insuring that the silver grain location is within 2 $\mu \mathrm{m}$ from the tritium-labeled ligand (Hendrickson and Edwards, 1978; Rogers, 1979). The density of labeling cannot be altered by gaps in apposition or differential pressure as is the case with film or predried emulsion (Rogers, 1979). Subtle or gross fluctuations in grain densities, especially at the edges of sections or at gray-white matter interfaces where section thickness may change, can be reliably attributed to receptor distribution heterogeneity. The emulsion does not slip or lift away from its 
TABLE II

Optical density of tritium-sensitive film exposed to rat coronal brain sections with [ ${ }^{3} \mathrm{H}$ ]naloxone-labeled opiate receptors

Computer-generated values produced errors ( \pm SEM) generally less than $1 \%$. Totally exposed film (opaque) has an optical density value of 2.0 .

\begin{tabular}{lc}
\hline \multicolumn{1}{c}{ Brain Region } & Optical Density \\
\hline Spinal cord & \\
Substantia gelatinosa & 0.40 \\
Ventral gray & 0.09 \\
Ventrolateral white matter & 0.04 \\
Adjacent non-tissue & 0.03 \\
& \\
Striatum & \\
Within patches & \\
$\quad$ Anterior & 0.69 \\
Middle & 0.56 \\
Posterior & 0.65 \\
Between patches & \\
Anterior & 0.29 \\
$\quad$ Posterior & 0.14 \\
Whole striatum & \\
$\quad$ Anterior tip & 0.48 \\
Anterior & 0.39 \\
Middle & 0.29 \\
Posterior & 0.18 \\
Posterior tip & 0.17 \\
& \\
Selected highest regions & \\
Habenular "streak" & \\
Nucleus ambiguus & 1.45 \\
Parabrachial nucleus & 1.14 \\
Nucleus of the solitary tract & 1.13 \\
Inferior colliculus & 0.97 \\
Mediodorsal nucleus of thalamus & 0.69 \\
Superior colliculus & 0.69 \\
Medial nucleus of amygdala & 0.67 \\
\hline & 0.52 \\
& 0.36 \\
\hline
\end{tabular}

position over the defatted section, so that its alignment with the section is insured. Figures 4 to 8 provide examples of these points, again in rat brain sections incubated in $\left[{ }^{3} \mathrm{H}\right]$ naloxone.

The caudal portions of the nucleus of the solitary tract are densely labeled with opiate receptors (Figs. $2 q$ and 4) as described originally (Atweh and Kuhar, 1977a). The bright-field photograph of a section with well preserved morphology (Fig. 4a) shows the nucleus at a caudal level just rostral to the area postrema. It is surrounded by the solitary tract laterally (cell-sparse area), the dorsal motor nucleus of the vagus (darkly staining oval cells) and the hypoglossal nucleus (darkly staining large multipolar cells) ventromedially, and the parasolitarius nucleus dorsolaterally (uniformly small cells).

Based on cytoarchitecture (Higgins and Schwaber, 1981), the subnuclear organization of the nucleus of the solitary tract can be correlated with receptor density. At this level, the parvocellular subnucleus (area subpostrema) lining the fourth ventricle is recognized by low cell density and low receptor density. The medial subnucleus (medial to the solitary tract) has a low density of medium size cells and moderate levels of receptor binding. The dorsomedial subnucleus (dorsomedial to the tract) has medium size fusiform cells and very dense $\left[{ }^{3} \mathrm{H}\right]$ naloxone binding. The lateral subnucleus (lateral to the tract) has various size cells and low binding levels. The solitary tract itself contains dense binding. Labeling in the vagus rootlets (Fig. $8 b$ ) is a well documented phenomenon (Atweh and Kuhar, 1977a; Atweh et al., 1978; Young et al., 1980). The dense labeling in the dorsomedial subnucleus is continuous caudally with similarly dense labeling throughout the commissural nucleus. The parasolitarius nucleus is easily recognized in dark-field illumination by the virtual absence of grains over it (Fig. $4 b$ ). The dorsal motor nucleus of the vagus and the hypoglossal nucleus are sparsely labeled.

The single neuron in Figure $4 c$ is a motor neuron of the hypoglossal nucleus. At this magnification, the nucleus, nucleolus, basal dendrites, and "tigroid" appearance of Nissl bodies attest to the preserved cell morphology. The silver grains surround but do not overlie the cell soma in any great number. This distribution could be obtained only if the ligand did not diffuse away from its receptor occupancy in the neuropil during any stage of the processing and if the emulsion remained adhered to the section surface.

The high resolution and fine grains of the emulsion stand in marked contrast to the coarse grained film image of a slightly more caudal section (Fig. $4 d$ ). The dense area of labeling is apparent, but the underlying structure is not available without staining and comparing the incubated section. Although this would provide valuable localization data, the picture shown in Figure $4 d$ represents the limits of film resolution, since no better resolution could be gained by higher magnification.

The dorsal horn of the spinal cord has received much attention as a site of opiate analgesia, and opiate receptors are found in high concentrations in laminae I and II (Atweh and Kuhar, 1977a). Photomicrographs show the distribution of $\left[{ }^{3} \mathrm{H}\right]$ naloxone binding, seen in dark-field illumination (Fig. 5, lower panel), and the distribution of cell types and the incoming dorsal root, seen in brightfield illumination (Fig. 5, upper panel). Very dense labeling overlies laminae I and II. The dorsal root, entering at the upper right, is devoid of label. Low to moderate labeling is found throughout the gray matter of the spinal cord (Fig. 2r), and very sparse labeling is found in discrete portions of the white matter (Table II).

Another example of labeling specificity is shown in Figure 6, which illustrates, by emulsion autoradiography, $\left[{ }^{3} \mathrm{H}\right]$ naloxone binding in the ventral tegmentum at the same level as in Figure 2j. The dense labeling entirely covers the medial terminal nucleus of the accessory optic fiber system and the thin tract of retinal axons entering from their lateral position between the cerebral peduncle and the pia-arachnoid (Atweh et al., 1978). Rostrally, the optic tract and nerve are diffusely and sparsely labeled (Fig. 2, $c$ to $f$ ). The two higher magnification photomicrographs (Fig. 6, $b$ and $c$ ) illustrate how this labeling is confined selectively to the nucleus and tract. The absence of silver grains in the immediately adjacent zones illustrates again that the ligand has not moved from the receptor during processing and that the emulsion has retained its perfect apposition to the section. Grain counts taken over two immediately adjacent areas, the nucleus and the contiguous pia-arachnoid, reveal a 30:1 

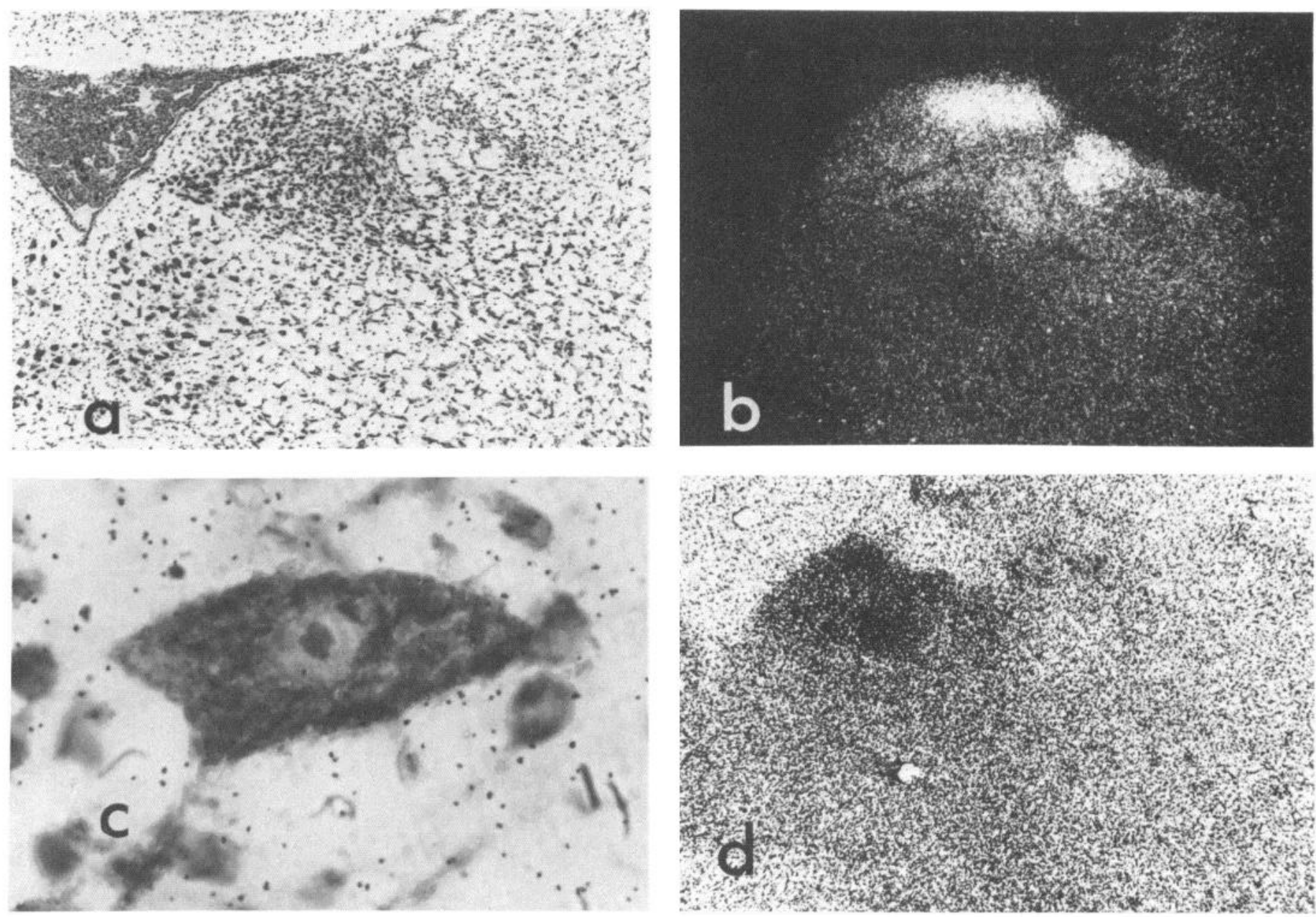

Figure 4. Bright-field $(a)$ and dark-field $(b)$ photomicrographs of the same section, which is an emulsion-coated coronal level of rat medulla labeled by $\left[{ }^{3} \mathrm{H}\right]$ naloxone, after 14 weeks exposure. Midline is to the left. The choroid plexus lies in the fourth ventricle just rostral to the area postrema. The caudal level of the nucleus of the solitary tract can be subdivided cytoarchitecturally. These subdivisions have correlates in opiate receptor distribution. See the text for further details. $c$, Oil immersion brightfield photomicrograph (magnification $\times 1,200$ ) of a single motor neuron of the hypoglossal nucleus from same section as in $a$ and $b$. Note the intracellular detail and location of silver grains in the overlying emulsion. $d$, Photograph of LKB film autoradiograph of a slightly more caudal level at the same magnification $(\times 45)$ as in $a$ and $b$. The heavily labeled area is continuous caudally with the densely labeled commissural nucleus.

ratio between a very dense receptor population and background labeling.

Opiate binding is found in a considerable number of fiber tracts throughout the brain, for example, in the fasciculus retroflexus and retinal axons (Fig. 6). When tritiated amino acids are used to mark axonal pathways, the autoradiography of axoplasmic transport shows silver grains tightly aligned in rows along axon trajectories. At low and medium magnification, the $\left[{ }^{3} \mathrm{H}\right]$ naloxone binding in tracts appears as more randomly arranged grains and does not resemble the picture of axon labeling by amino acids. At high magnification in bright-field, however, a number of grains do align themselves in rows, suggesting their localization to individual retinal axons entering the medial terminal nucleus.

Opiate receptor binding to the rat brainstem at the level of the locus coeruleus is shown in Figure 7. Heavily labeled structures include the inferior colliculus, the ventral gray substance, locus coeruleus, and the parabrachial nucleus. The locus coeruleus is densely labeled by $\left[{ }^{3} \mathrm{H}\right]$ naloxone throughout its entirety, but the binding in the parabrachial nucleus reveals intricate patterns depending on the level examined (compare Fig. 2, $n$ and $o$; see also Atweh and Kuhar, 1977b).

Elsewhere at this level, light labeling is diffuse but shows definite patterns visible even at the lowest magnifications (Fig. 7c), which show subtle borders that correspond to the cytoarchitectural boundaries. (Compare in Fig. $7 b$ the distribution of darkly staining large cells in the motor nucleus of the trigeminus ventral to the parabrachial nucleus with a "hole" in the sparse receptor distribution in surrounding structures, visible in Fig. 7, $c$ and $d$.) Faint lines of label seen at low magnification in Figure $7 c$ are shown at higher magnification in Figure $7 e$. The labeling is concentrated in the granular layer of the ventral cochlear nucleus and in the lateral aspect of the spinal trigeminal tract. Though sparse, the receptors are nevertheless highly discretely localized. 

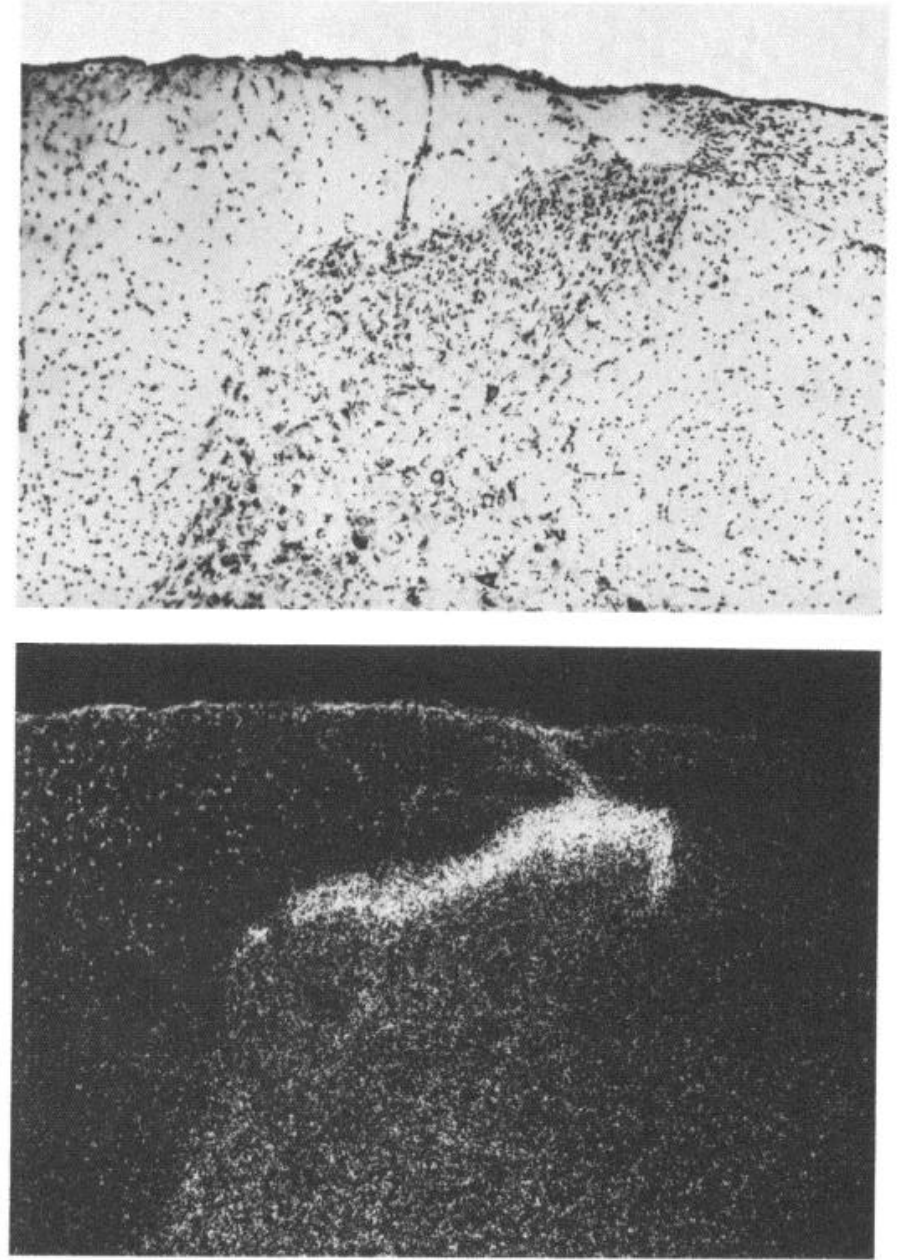

Figure 5. Bright-field (upper) and dark-field (lower) photomicrographs of the same emulsion-coated coronal section of dorsal horn of rat cervical spinal cord labeled by $\left[{ }^{3} \mathrm{H}\right]$ naloxone after 14 weeks exposure. The dorsal column and midline are to the left, a dorsal root is at the upper right. Dense opiate receptor labeling overlies laminae I and II of Rexed. Intensely stained glial cells appear as larger white dots in dark-field illumination, while autoradiographic grains are the smaller white dots. Magnification $\times 45$.

The bright-field photograph of the ventral cochlear nucleus labeling (Fig. $7 f$ ) shows grains mostly situated among and between the cells of the granular layer (Mugnaini et al., 1980), showing again the highly specific localization to neuropil. The choroid plexus of the lateral recess is unlabeled. Comparing grain counts in these two contiguous zones, the sparse labeling of the granular layer is 5 to 10 times above background levels in the choroid plexus. The extremely sparse labeling that pervades the rest of the ventral cochlear nucleus is still 2 to 3 times above background levels. The key to achieving this kind of resolution lies in the low background even after 14 weeks exposure. The factors that make this possible are: (i) in vitro binding conditions with optimized stereospecific binding, (ii) the proper use of low noise emulsion like Kodak NTB-2, and (iii) clean slides and fastidious darkroom procedures (Rogers, 1979).

Medullary levels of rat brain contain very low levels of $\left[{ }^{3} \mathrm{H}\right]$ naloxone binding (Fig. 8) with a few exceptions: dense labeling is confined to the vagus nerve rootlets and the nucleus ambiguus, and moderate labeling overlies the rostral portions of the nucleus of the solitary tract, the dorsal accessory nucleus of the inferior olive, and the molecular layer of the dorsal cochlear nucleus (Fig. $8 b$ ). The binding levels visible in the low power dark-field photograph (Fig. $8 b$ ) can be compared with earlier chartings of this same level (Atweh and Kuhar, 1977b). There is good general agreement, though the opiate receptors in the inferior olive were not described previously. The low-to-moderate levels of $\left[{ }^{3} \mathrm{H}\right]$ naloxone binding throughout this structure can be seen in Figure $8 d$.

The distribution and density of opiate receptors throughout a large extent of brain can be appreciated in horizontal (Fig. 9) and sagittal sections (Fig. 10). Greater detail is afforded by these photographs than has been available by results of previous techniques. A number of previously unreported opiate receptor-rich areas are visible, though their precise descriptions must await subsequent works. The potential for detailed descriptions of receptor localizations in relation to cytoarchitecture is underscored by these illustrations.

We also stress the potential for studying different receptors or receptor subtypes in adjacent sections from the same animal by this technique (Figs. 10 and 11). The opiate receptor subtypes are contrasted dramatically by their differential distribution in the rat striatum (Goodman et al., 1980; Herkenham and Pert, 1981). In sagittal sections, $\left[{ }^{3} \mathrm{H}\right]$ naloxone, under $\mu$-binding conditions (Bowen et al., 1981), marks striatal patches, a subcallosal streak, and slender fiber fascicles extending ventrocaudally (Fig. 10). By contrast, D-Ala-D-Leu- $\left[{ }^{3} \mathrm{H}\right]$ enkephalin, depending upon the binding conditions used (Bowen et al., 1981), can mark receptors distributed rather diffusely over the neuropil of the entire striatum, nearly obscuring patches and streaks that also are labeled (Fig. 11).

By the present method, it is possible to process fresh, unfixed postmortem human tissue with tissue quality as good as that shown in the human basal forebrain in Figure 12. The dense band of $\left[{ }^{3} \mathrm{H}\right]$ naloxone binding lies just deep to the lateral olfactory tract in the anterior perforated substance. The corresponding olfactory areas in the rat are very sparsely labeled. Such marked species differences can be found in many brain regions, including cortex (Herkenham et al., 1981) and striatum (Moon Edley et al., 1981).

\section{Discussion}

The method for receptor binding on slide-mounted tissue sections is immediately applicable for visualization of the many well characterized ligand-receptor binding sites previously studied only with tissue homogenates. Moreover, liquid spectrophotometry of the sections provides sensitive and reliable quantitative binding data (Table I). Obviously, brain regions which remain constant in size and receptor density for several millimeters should be chosen for quantitative studies. For example, we have utilized rat striatum for quantitating opiate receptor ligand selectivity patterns (Bowen et al., 1981) and rat olfactory bulb for studies of phencyclidine receptors (Quirion et al., 1981), since 60 or more nearly iden- 

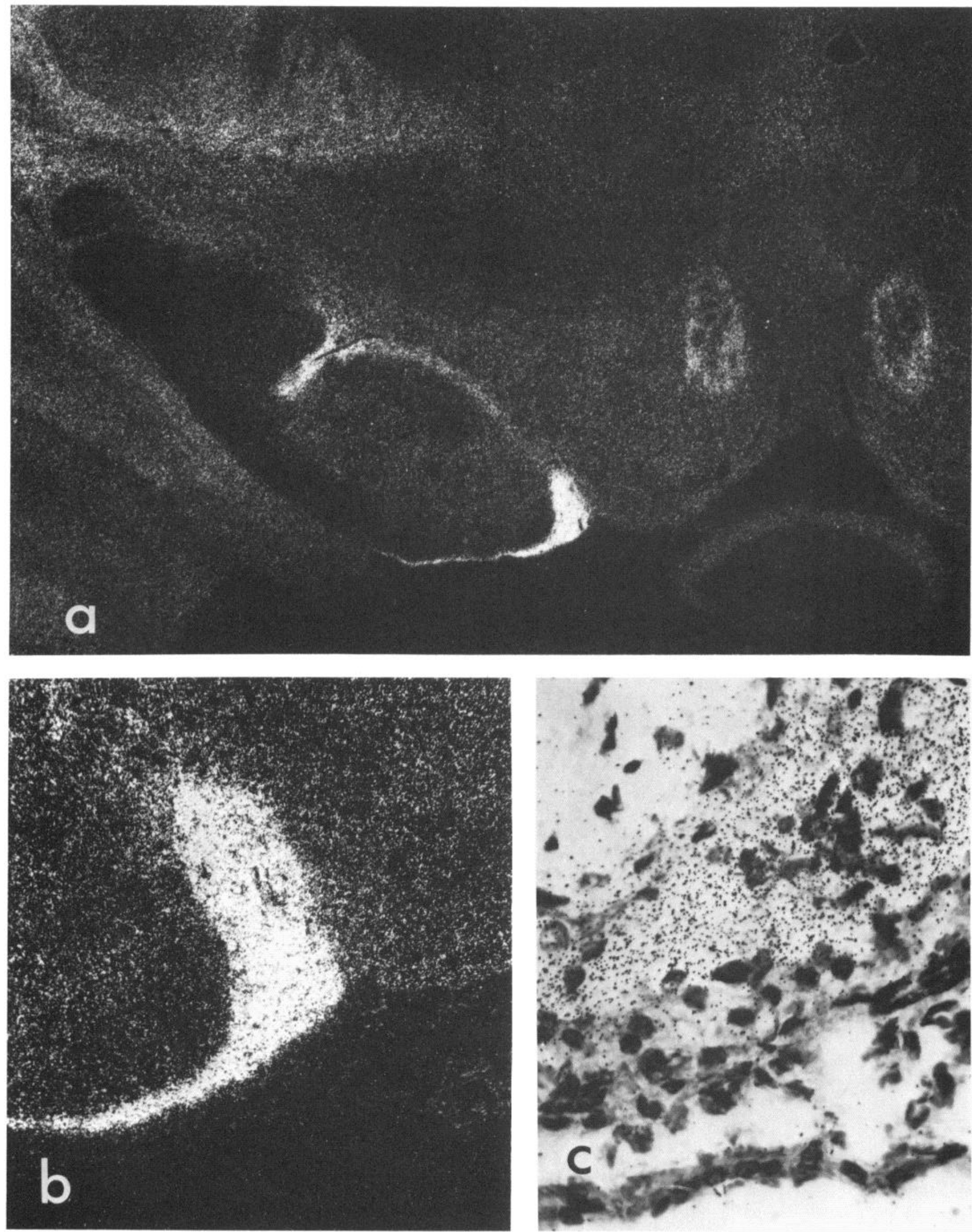

Figure 6. Photomicrographs at three different magnifications- $(a) \times 40,(b) \times 120$, and $(c) \times 585$ (but the same orientation) of rat ventral tegmentum labeled by $\left[{ }^{3} \mathrm{H}\right]$ naloxone after 14 weeks exposure. The level in the coronal plane is just rostral to A2180 $\mu$ of König and Klippel (1963). $a$, Low to moderate labeling marks the posterior nucleus and the ventral lateral geniculate nucleus of the thalamus (upper left), the ventral hippocampus (lower left), and the ventral tegmental area and the outer shell of the posterior mamillary nucleus (lower right). Dense labeling marks the substantia nigra pars compacta in discrete portions and the shell of the habenulointerpedunuclar tract. Very dense labeling fills the medial terminal nucleus of the accessory optic system and the thin fascicle of afferent retinal axons. Dark-field $(b)$ and bright-field $(c)$ views of the medial terminal nucleus illustrate how the label is confined to the cytoarchitecturally defined structures. 

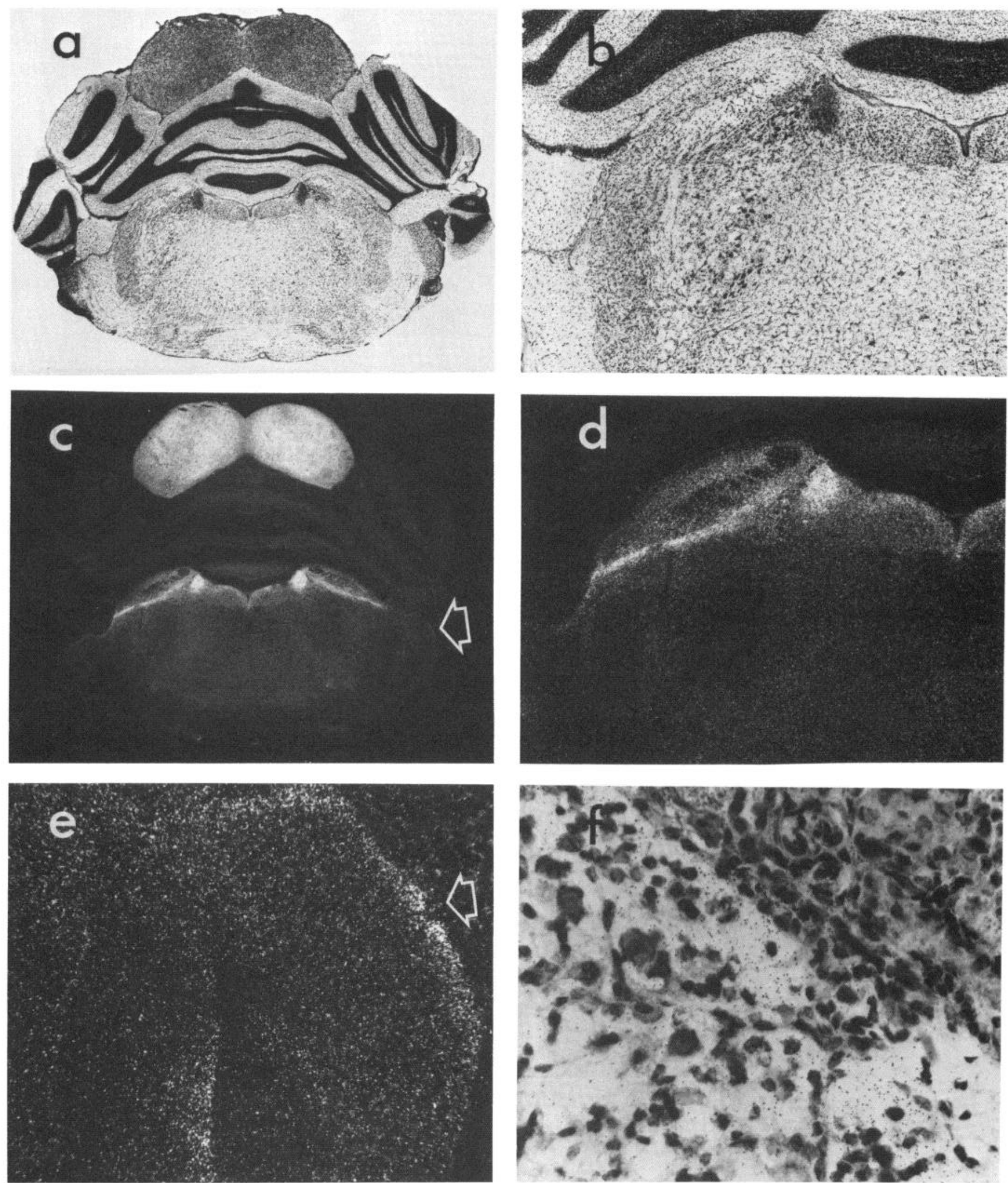

Figure 7. Photomicrographs of the same coronal section of rat brainstem and cerebellum incubated in [ $\left.{ }^{3} \mathrm{H}\right]$ naloxone, emulsioncoated, and exposed for 14 weeks before developing. In bright-field illumination $(a$ and $b$ ), cytoarchitectural detail shows the distinctive variety of neurons in the region of the locus coeruleus (oval area at the roof of the brainstem), the mesencephalic nucleus of the trigeminus (small large celled area just lateral to the locus coeruleus), the parabrachial nucleus (smaller closely spaced cells surrounding the brachium conjunctivum), and the motor nucleus of the trigeminus (large, darkly staining cell group to the left of center in $b$ ). Magnification: $a$ and $c, \times 7.6 ; b$ and $d, \times 21$. In dark-field illumination $(c$ and $d)$, dense labeling fills the posterior inferior colliculus (dorsalmost structure), locus coeruleus, and a thin ventrolateral stratum of the parabrachial nucleus. Moderate labeling elsewhere shows gradients and borders that correlate with nuclear or fiber tract boundaries. See the text for further details. The arrows in $c$ and $e$ (magnification $\times 56$ ) point to the granule cell layer of the ventral cochlear nucleus. This region is greatly magnified $(\times 350)$ in $f$, where the choroid plexus of the lateral recess appears in the upper right. 

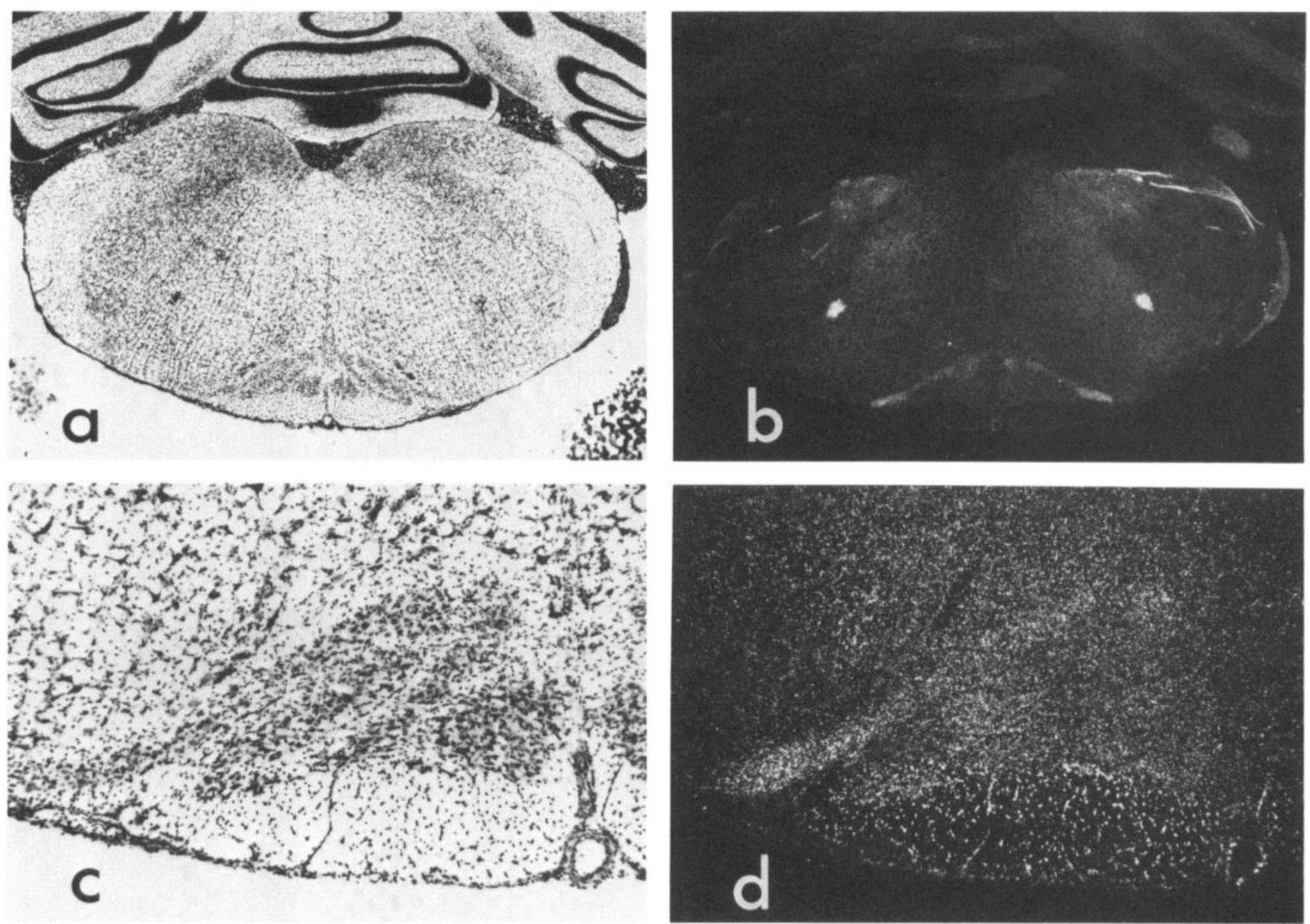

Figure 8. Photomicrographs of coronal sections of rat medulla incubated in $\left[{ }^{3} \mathrm{H}\right]$ naloxone, emulsion-coated, and exposed for 14 weeks. Bright-field $(a)$ and dark-field $(b)$ views of the same section magnified $\times 11$ are shown. In $b$, typically sparse labeling of medullary reticular formation and raphe nuclei is in contrast to the localized, dense labeling in the vagus nerve rootlets (strands in upper medulla), nucleus ambiguus (single spots), and dorsal accessory inferior olive (in ventral medulla just dorsal to pyramidal tract). Detail of inferior olive labeling from another section is shown in bright-field $(c)$ and dark-field $(d)$ views magnified $\times 43$. Labeling is densest in the dorsal accessory olive.

tical sections per rat are readily available from each of these brain areas.

Quantitative assessment of receptor density also can be obtained by densitometry of images made on tritiumsensitive film (Palacios et al., 1981a; Penney et al., 1981;
Rainbow et al., 1982; Unnerstall et al., 1982). The measurement in units of relative optical density shown for $\left[{ }^{3} \mathrm{H}\right]$ naloxone binding in various regions of rat brain (Table II) is very similar to the regional distribution of autoradiographic grains after in vivo injection of $\left[{ }^{3} \mathrm{H}\right]$

Figure 9. Dark-field photograph of an emulsion-coated horizontal section at the level of the dorsal thalamus (same level as in Fig. A38 of Zeman and Innes, 1963). Opiate receptors labeled by $\left[{ }^{3} \mathrm{H}\right]$ naloxone are shown after 15 weeks exposure. Listed from top (rostral) to bottom (caudal), receptors predominate in the glomeruli and external plexifom layers of the olfactory bulb, three layers of cerebral cortex, striatum, thalamus, brainstem, and hippocampus (lateral to brainstem). The labeling shows distinctive patterns within each of these regions. The striatum displays the characteristic subcallosal streak and patches. The most lateral patches are aligned to form a second, punctuated streak about $800 \mu \mathrm{m}$ inside of the subcallosal streak. The cortical labeling is relatively more dense in the medial frontal, entorhinal, and presubicular areas, and less dense in the primary somatosensory area. The classic habenular stripe runs the length of the habenula and, in addition, a discrete ball of dense labeling occupies a small portion of the lateral habenula. Most of the dorsal thalamus is densely labeled. However, the anterodorsal nucleus, just rostrolateral to the habenula and caudal to the fimbria, is free of label. The subfornical organ appears as a receptor-rich spot on the midline within the region of the hippocampal commissure. Rostral to this, the septum is very receptor sparse. The relatively receptor-free anterior pretectal nucleus marks the posterior border of the thalamus. The inferior colliculus (the most caudal labeled structure) is more heavily labeled in the external nucleus than in the central portion. Bilaminated labeling (stratum lacunosum-moleculare and stratum pyramidale-oriens) in the hippocampus is most dense in the CA2-3 region. The septum, subcortical white matter, and cerebellum (invisible, at bottom) are the most receptor-sparse regions. The fimbria and hippocampal commissure do show sparse labeling. Magnification $\times 11$. 


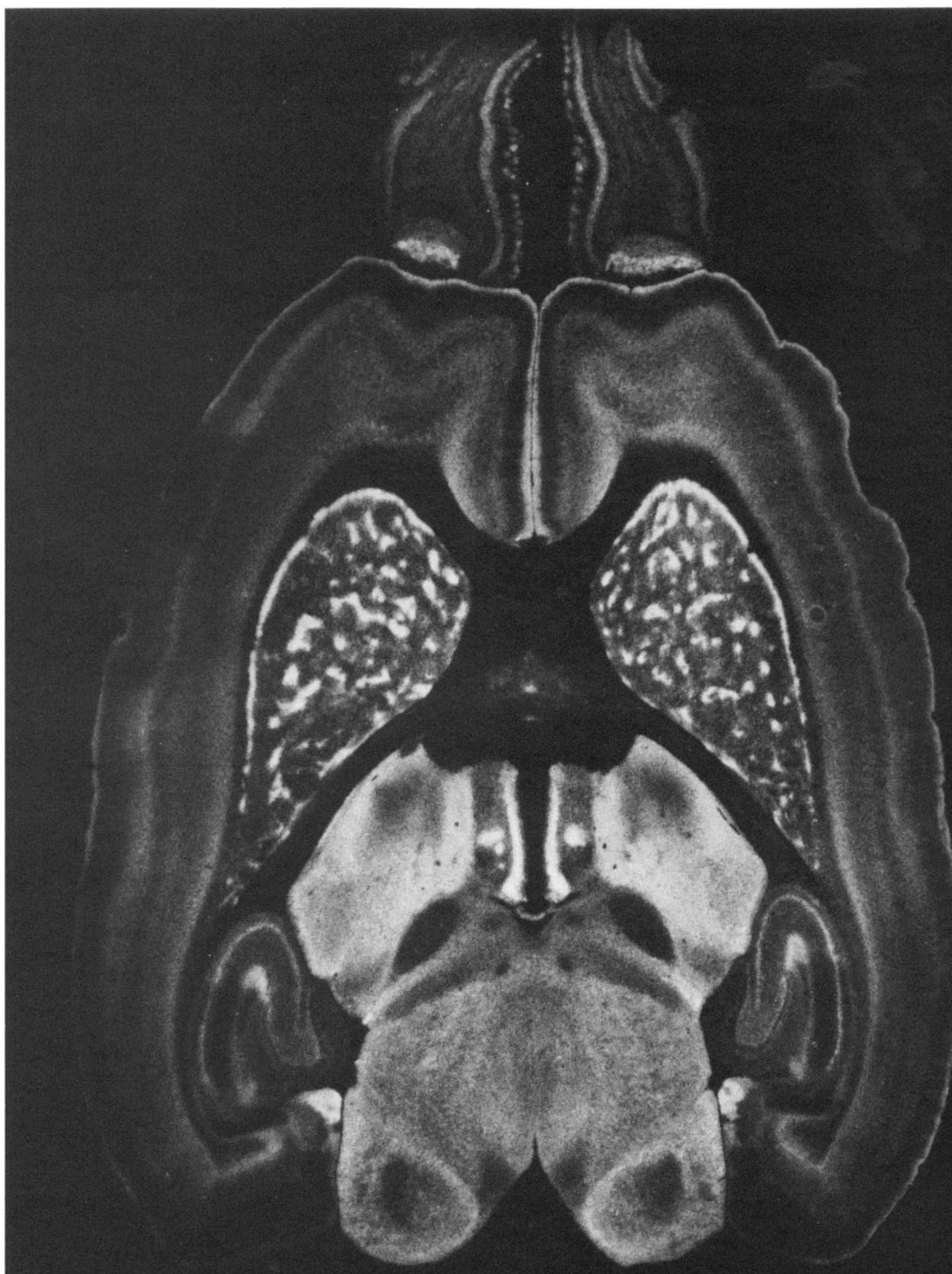




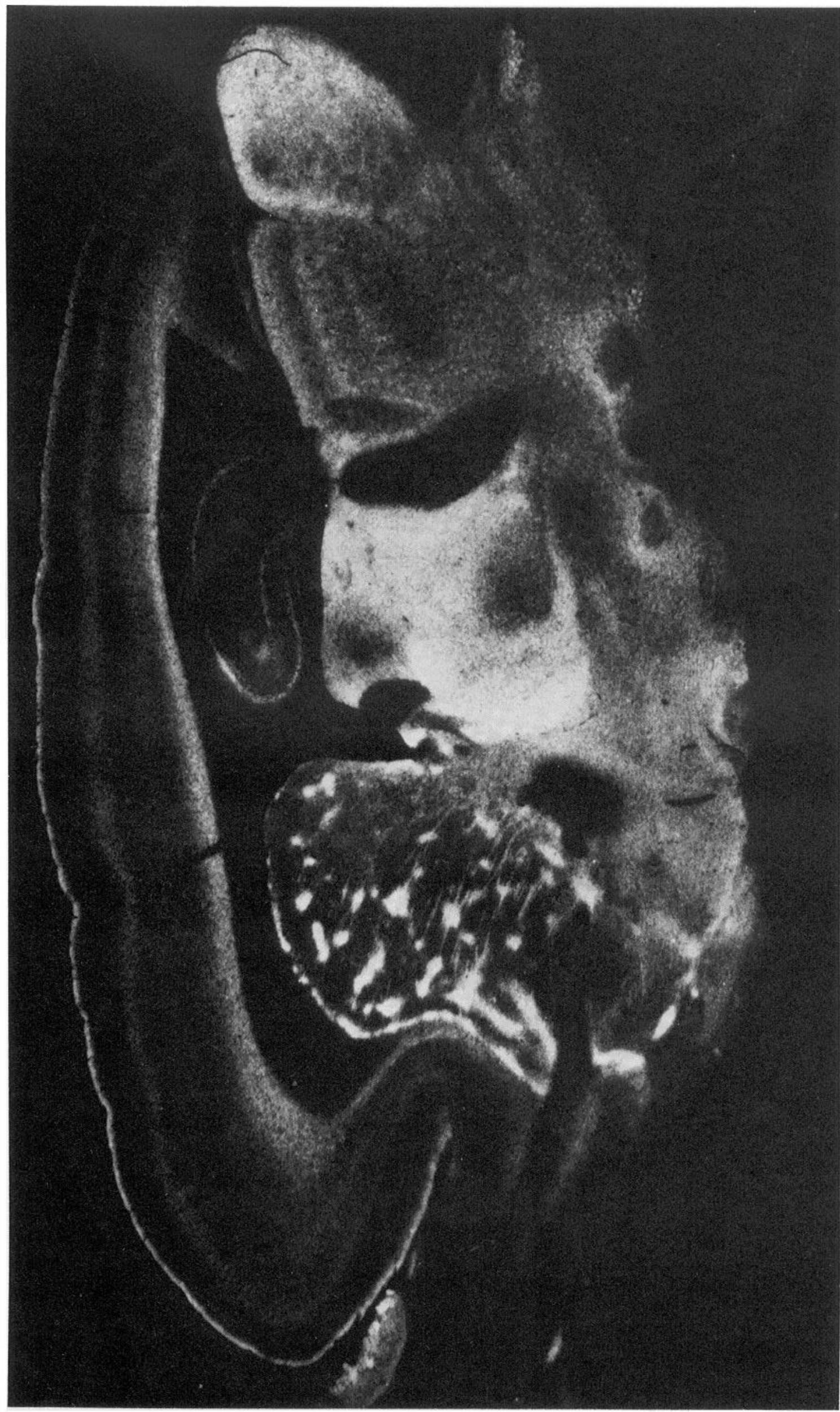

.2.

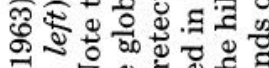

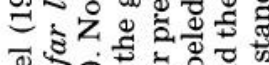
『 국웅

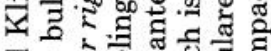
สี 귱

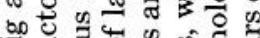

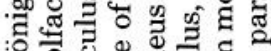
이월 फ ₹

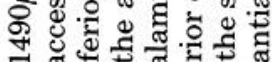
ส

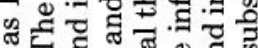
ब

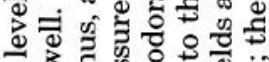
है.

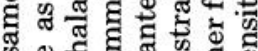

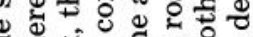
\&

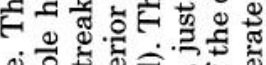

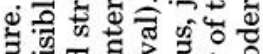

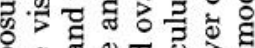
: भิ⿵人 ه. 3 됭 की

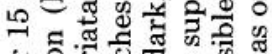
๑. क ธี 要 屯. 范

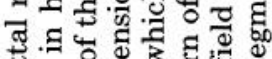
.

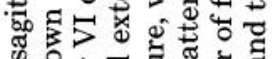
สึ ฐ ส ๙

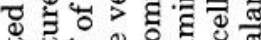
此

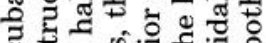

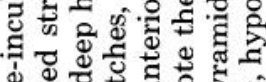
๓

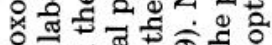

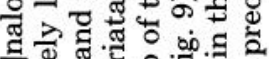

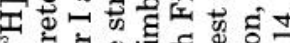

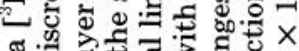
๘\%

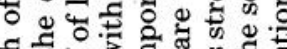

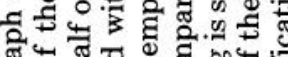

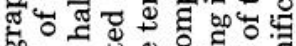
施. 苟 5 ๘ ส

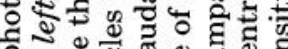
ㄴ. $\tau$ 궁

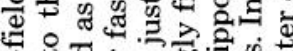

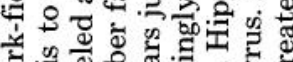
สุ.

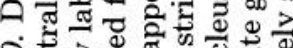

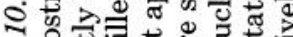

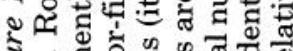
ริ

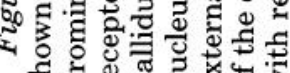




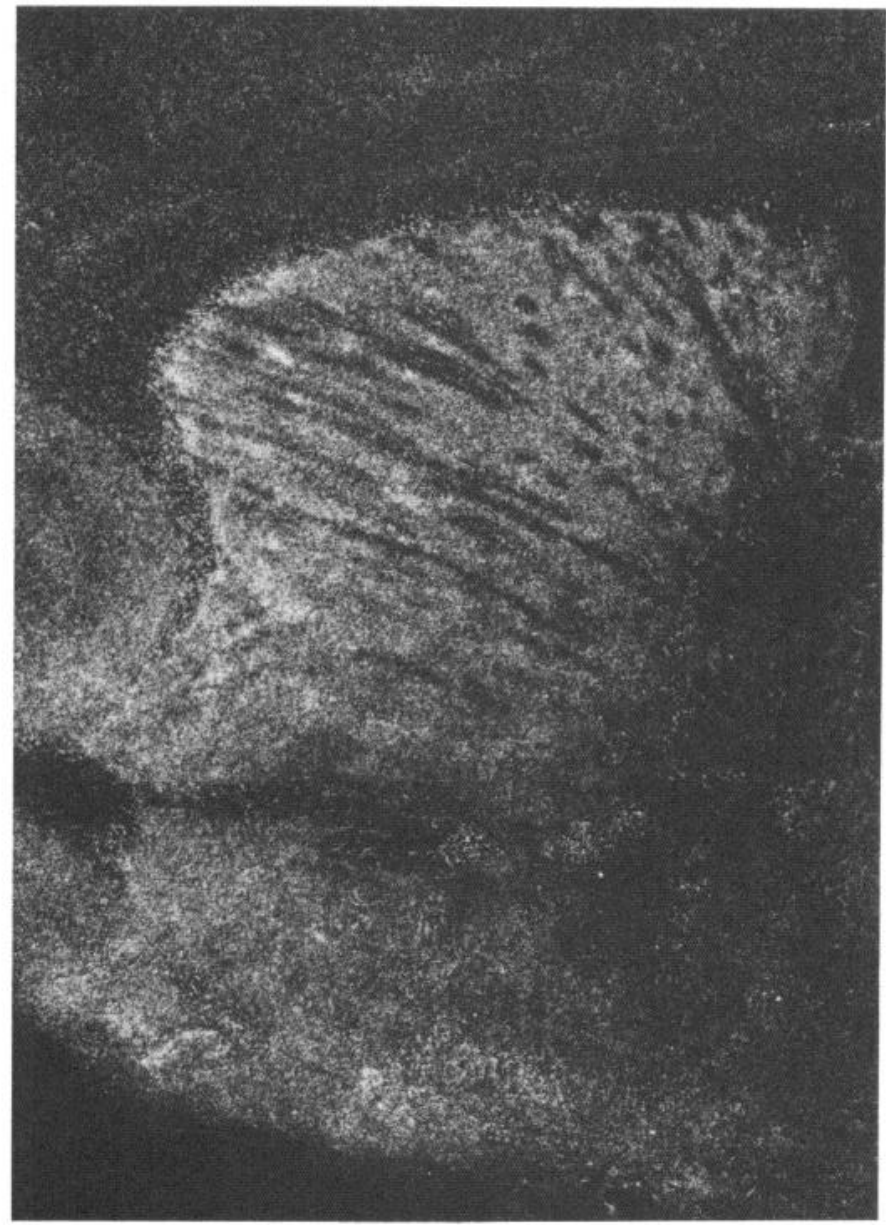

Figure 11. Dark-field photomicrograph of rat parasagittal striatal section incubated in D-Ala-D-Leu- $\left[{ }^{3} \mathrm{H}\right]$ enkephalin, emulsion-coated, and exposed for 15 weeks. This is the same level as in Figure 10. The opiate receptors marked by the peptide are aggregated in patches and in the subcallosal streak, but these are nearly obscured by the diffuse labeling that fills the rest of the striatum and basal forebrain. Receptor-sparse areas are the intrastriatal fiber fascicles, the anterior and temporal limbs of the anterior commissure, the subcortical white matter, and the internal capsule. Magnification $\times 17$.

diprenorphine (Pert et al., 1976a; Pearson et al., 1980). Computer-assisted densitometry (Goochee et al., 1980) is several orders of magnitude faster than visual counts of grains. Tritium or ${ }^{14} \mathrm{C}$ standards can be used to express the binding in terms of moles of ligand bound per gm of protein in the tissue (Penney et al., 1981; Unnerstall et al., 1982), permitting comparison of receptor densities on films with those from brain homogenates.

We emphasize the advantages of working with unfixed tissue. Prior fixation, no matter how mild, may denature the receptor to some extent and reduce specific binding or alter its properties. Elimination of fixatives will obviate the need for preliminary experiments designed to assess the loss or alteration of binding by the fixative for every new receptor. Also, fixatives often cause chemographic artifacts in the emulsion or film when they are not washed out of the tissue completely before autoradiography.

Vapor fixation of incubated and dried tissue not only preserves morphology but also seems able to fix a number of normally reversible ligands in the receptor vicinity, since receptor distribution patterns appear unaltered by the defatting or dipping procedure. Presumably, copious cross-linkage of the many amino acid residues susceptible to nucleophilic or electrophilic attack in the tissue protein occurs (Pearse, 1980), trapping the ligand in the receptor vicinity. It is possible that covalent bonds between ligands of suitable chemistry and reactive groups on receptor vicinity proteins contribute to the fixation process.

Some loss of a given radioligand in aqueous solution after formaldehyde vapor fixation as measured by liquid scintillation spectrometry does not obviate the utility of that radioligand for receptor visualization by this method. For example, we have demonstrated the autoradiographic distribution of $\left[{ }^{3} \mathrm{H}\right]$ dihydromorphine binding in rat striatum after fixation at $80^{\circ} \mathrm{C}$ and defatting (Bowen et al., 1981) under conditions which can produce some loss of label (data not shown). Computer analysis of autoradiographs (as in Fig. 3) of the residual binding reveal no selective alteration in labeling patterns after defatting.

Film autoradiography. Though it is a fairly low level of resolution, the overview of $\left[{ }^{3} \mathrm{H}\right]$ naloxone binding in rat brain provided by the film (Fig. 2) reveals a richness and variety of opiate receptor binding throughout the brain, especially rostrally. Except for a few notably receptordense areas, the medulla and caudal brainstem are sparsely populated. In contrast, the forebrain is epitomized by the well characterized intricate striatal patch network that shows striking consistencies from brain to brain. Opiate receptors are aggregated in layers in laminated structures and are dense in the most superficial layers of most of these. They densely occupy sensory way stations at many subcortical levels. These include both primary sensory nuclei (Atweh and Kuhar, 1977a, b; Herkenham and Pert, 1980) and later order nuclei, such as the "olfactory" portions of the amygdala (Fig. 2 $h$ to $j$ ) and bed nucleus of the stria terminalis (Fig. $2 f$ ), the "auditory" inferior colliculus (Fig. 2, $m$ to $o$ ), the "taste" relay nucleus of the thalamus (Fig. 2i), the "thirst" detection point in the subfornical organ (Fig. 2f), and visceral sensory portions of the nucleus of the solitary tract (Fig. $2 q$ ) and the parabrachial nucleus (Fig. $2 n$ and $o$ ). In contrast, the systems that are involved in the central programming of motor control are generally uniformly opiate receptor sparse.

A generalization derived from the examination of regional homogenates from monkey and human brain (Hiller et al., 1973; Kuhar et al., 1973; LaMotte et al., 1978) not supported by the overall distribution in rat brain is that opiate receptors predominate in limbic areas. Core limbic structures, the hypothalamus and preoptic area (Fig. 2, $e$ to $i$ ), and septum (Fig. 2, $c$ to $e$ ) are notable for the relative scarcity of opiate receptors in the rat. In many other limbic areas, such as the amygdala (Fig. 2, $f$ to $i$; Herkenham, 1981), labeling is restricted to discrete portions, an observation that deserves detailed future analysis.

Another curious generalization is that the brain areas in rat often associated with pain processing (Pert, 1978), except for the dorsal horn of the spinal cord (Fig. $2 r$ ), are surprisingly receptor sparse. These include the medullary raphe nuclei (Fig. $2, n$ to $p$ ), the periaqueductal gray 

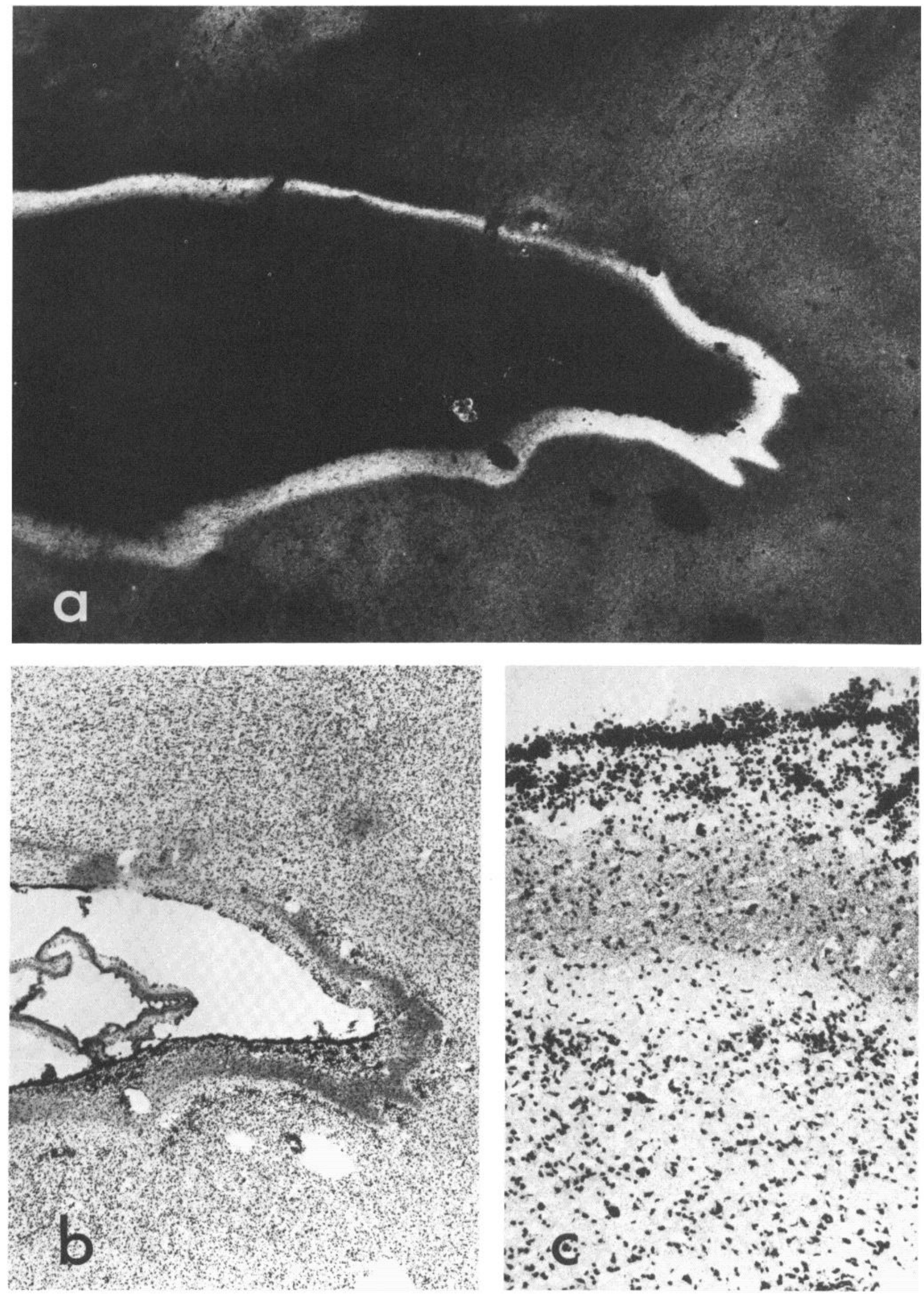

Figure 12. Dark-field ( $a$; magnification $\times 13$ ) and bright-field ( $b$ and $c$ ) photomicrographs of a human coronal section in the region of the lateral olfactory tract and basal forebrain. The level approximates that of Figure 50 of De Armond et al. (1974). The substantia innominata and preoptic areas lie dorsally. The middle cerebral artery appears in $b$ (magnification $\times 13$ ). A dense band of label, not found in other species, lies just deep to the olfactory tract in regions where the tract terminates. The highest magnification $(c, \times 90)$ shows the discrete position of the labeled band in the molecular layer of the ventral bank. 
substance (Fig. $2, j$ to $m$ ), and the intralaminar (Fig. $2 h$ ) and parafascicular-center median (Fig. $2 i$ ) nuclei of the thalamus. Perhaps a more careful consideration of species differences would be revealing in these regards.

High resolution autoradiography. The opiate receptor and others will provide valuable information as markers for brain heterogeneity as adjuncts to current histological stains for cells, fibers, and enzymes. For example, early controversies over the delineation of "substantia gelatinosa" as lamina II or as laminae II and III together (Willis and Coggshell, 1978) were based on the failure of the cell stains to distinguish the layers. The highly discrete localization of $\left[{ }^{3} \mathrm{H}\right]$ naloxone binding to upper half of the contested zone (Fig. 5, lower panel), which is easily visualized in the same section that shows good cytoarchitectural detail (Fig. 5, upper panel), serves to resolve this matter. In conjunction with immunohistochemical localization of enkephalin and other peptides to this same narrow zone (Hökfelt et al., 1977; Sar et al., 1978; Uhl et al., 1979; Gibson et al., 1981), there is now supportive evidence to call the labeled zone layer II, the substantia gelatinosa.

The present method is also well suited for the comparative study of several receptor systems in adjacent sections from the same animal. Analysis of receptor subtypes are made in this fashion (Goodman et al., 1980; Pert et al., 1980; Wamsley et al., 1980; Herkenham and Pert, 1981; Palacios et al, 1981b). The striatum provides an excellent preparation for studies of these kinds. For example, opiate alkaloids, such as dihydromorphine and naloxone, bind almost exclusively to rat striatal patches, while opiate peptides, such as D-Ala-D-Leu-enkephalin, bind more diffusely to striatum (Goodman et al., 1980; Bowen et al., 1981). Autoradiography used as a biochemical tool has revealed that appropriate allosteric effectors added to the incubation medium produce the patchy striatal pattern even when D-Ala-D-Leu- $\left[{ }^{3} \mathrm{H}\right]$ enkephalin, a " $\delta$ "-opiate (Lord et al., 1977), is utilized to label receptors (Bowen et al., 1981). From considerations of biochemical, autoradiographic, and pharmacological data, Pert (1981) suggested that GTP-sensitive "Type 1" opiate receptors in rat striatal patches can assume several conformations $(\mu, \delta$, etc.), while diffuse "Type 2 " receptors are more conformationally restricted to the $\delta$-ligand selectivity pattern.

The mapping of brain receptors has proceeded in parallel with the chemical identification and immunohistochemical localization of the neurons, axons, and terminal processes that manufacture, transport, and secrete endogenous neurochemicals that bind to the receptors. In the case of the opiates, both approaches are currently identifying increasing numbers of opiatergic systems. However, the wide ranging distribution of opiate receptors, appreciated by the greater sensitivity and resolution offered by the present technique, leads to a new concern: that the detection of at least some specific opiate receptor binding in almost every area of the brain might mean that this binding is not associated with a synaptic assembly or an opiate peptide-secreting neuron. Probably, further improvements in the sensitivity of immunohistochemistry will reveal additional cellular sources of opiatergic systems. In fact, a recent study has observed enkephalin-positive neurons and nerve processes in a number of previously unreported brain areas, including the olfactory bulb, the lateral, medial, and basolateral amygdaloid nuclei, hippocampus, neocortex, medial nucleus of the accessory optic tract, ventral tegmental nucleus, and locus coeruleus (Finley et al., 1981). All of these areas issue local collaterals or longer axons which terminate in patterns that provide a very striking fit with portions of the receptor distributions shown here. Concurrent immunohistological visualization of tracts and autoradiographic visualization of their receptors is likely to yield more conclusive information about the neurochemical coding of brain neurocircuitry.

\section{References}

Atweh, S. F., and M. J. Kuhar (1977a) Autoradingraphic localization of opiate receptors in rat brain. I. Spinal cord and lower medulla. Brain Res. 124: 53-67.

Atweh, S. F., and M. J. Kuhar (1977b) Autoradiographic localization of opiate receptors in rat brain. II. The brain stem. Brain Res. 129: 1-12.

Atweh, S. F., and M. J. Kuhar (1977c) Autoradiographic localization of opiate receptors in rat brain. III. The telencephalon. Brain Res. 134: 393-405.

Atweh, S. F., L. C. Murrin, and M. J. Kuhar (1978) Presynaptic localization of opiate receptors in the vagal and accessory optic systems: An autoradiographic study. Neuropharmacology 17: 65-71.

Bowen, W. D., S. Gentleman, M. Herkenham, and C. B. Pert (1981) Interconverting $\mu$ - and $\delta$-forms of Type 1 opiate receptors in rat striatal patches. Proc. Natl. Acad. Sci. U. S. A. 78: 4814-4822.

Costa, T., D. Rodbard, and C. B. Pert (1979) Is the benzodiazepine receptor coupled to a chloride anion channel? Nature 277: 315-316.

Cowan, W. M., D. I. Gottlieb, A. E. Hendrickson, J. L. Price, and T. A. Woolsey (1972) The autoradiographic demonstration of axonal connections in the central nervous system. Brain Res. 37: 21-51.

Creese, I., and S. H. Snyder (1975) Receptor binding and pharmacological activity of opiates in the guinea pig intestine. J. Pharmacol. Exp. Ther. 194: 205-219.

Creese, I., G. W. Pasternak, C. B. Pert, and S. H. Snyder (1975) Discrimination by temperature of opiate agonist and antagonist receptor binding. Life Sci. 15: 1837-1842.

De Armond, S. J., and M. M. Dewey (1974) Structure of the Human Brain: A Photographic Atlas, Oxford University Press, New York.

Finley, J. C. W., J. L. Maderdrut, and P. Petrusz (1981) The immunocytochemical localization of enkephalin in the central nervous system of the rat. J. Comp. Neurol. 198: 541-565.

Gibson, S. J., J. M. Polak, S. R. Bloom, and P. D. Wall (1981) The distribution of nine peptides in rat spinal cord with special emphasis on the substantia gelatinosa and on the area around the central canal (lamina X). J. Comp. Neurol. 201: 65-79.

Goldstcin, A., L. J. Lowney, and B. K. Pal (1971) Stereospecific and nonspecific interactions of the morphine congener levorphanol in subcellular fractions of mouse brain. Proc. Natl. Acad. Sci. U. S. A. 68: 1742-1747.

Goochee, C., W. Rasband, and L. Sokoloff (1980) Computerized densitometry and color coding of $\left[{ }^{14} \mathrm{C}\right]$ deoxyglucose autoradiographs. Ann. Neurol. 7: 359-370.

Goodman, R. R., S. H. Snyder, M. J. Kuhar, and W. S. Young, III (1980) Differentiation of delta and mu receptor localizations by light microscopic autoradiography. Proc. Natl. Acad. Sci. U. S. A. 77: 6239-6243.

Hendrickson, A., and S. B. Edwards (1978) The use of axonal transport for autoradiographic tracing of pathways in the 
central nervous system. In Neuroanatomical Research Techniques, R. T. Robertson, ed., pp. 241-290, Academic Press, New York.

Herkenham, M. (1981) Autoradiographic localization of opiate receptors in the cortex, thalamus and amygdala of the rat. Anat. Rec. 199: 111A-112A.

Herkenham, M., and C. B. Pert (1980) In vitro autoradiography of opiate receptors in rat brain suggest loci of "opiatergic" pathways. Proc. Natl. Acad. Sci. U. S. A. 77: 5532-5536.

Herkenham, M., and C. B. Pert (1981) Mosaic distribution of opiate receptors, parafascicular projections and acetylcholinesterase in the rat striatum. Nature 291: 415-418.

Herkenham, M., S. Moon Edley, and C. B. Pert (1981) Opiate receptor distribution in mammalian cortex: A comparative autoradiographic study. Soc. Neurosci. Abstr. 7: 436.

Higgins, G. A., and J. S. Schwaber (1981) Subnuclear organization and topography of forebrain inputs to the nucleus tractus soliatrius of the rabbit. Soc. Neurosci. Abstr. 7: 116.

Hiller, J. M., J. Pearson, and E. J. Simon (1973) Distribution of stereospecific binding of the potent narcotic analgesic etorphine in the human brain: Predominance in the limbic system. Res. Commun. Chem. Pathol. Pharmacol. 6: 1052-1062.

Hökfelt, T., A. Ljungdahl, L. Terenius, R. P. Elde, and G. Nilsson (1977) Immunohistochemical analysis of peptide pathways possibly related to pain and analgesia: Enkephalin and substance P. Proc. Natl. Acad. Sci. U. S. A. 74: 30813085 .

Hollenberg, M. D., and P. Cuatrecasas (1976) Methods for the biochemical identification of insulin receptors. In Methods in Receptor Research, Part II, M. Bleecher, ed., pp. 429-477, Marcel Dekker, New York.

Kent, J. L., C. B. Pert, and M. Herkenham (1981) Ontogeny of opiate receptors in rat forebrain: Visualization by in vitro autoradiography. Dev. Brain Res. 2: 487-504.

König, J. F. R., and R. A. Klippel (1963) The Rat Brain: A Stereotaxic Atlas of the Forebrain and Lower Parts of the Brain Stem, Krieger, Huntington, N Y.

Kuhar, M. J., and H. I. Yamamura (1975) Autoradiographic localization of the muscarinic receptor in rat brain. Nature 253: 560-561.

Kuhar, M. J., C. B. Pert, and S. H. Snyder (1973) Regional distribution of opiate receptor binding in monkey and human brain. Nature 245: 447-450.

LaMotte, C. C., A. Snowman, C. B. Pert, and S. H. Snyder (1978) Opiate receptor binding in rhesus monkey brain: Association with limbic structures. Brain Res. 155: 374-379.

I arsson, B., and S. Ullberg (1977) A rapid film for gross autoradiography with tritium. Acta Pharmacol. Toxicol. (Copenh.) Suppl. $141: 48-49$.

Lewis, M. L., A. Pert, C. B. Pert, and M. Herkenham (1981) Laminar analysis of opiate receptor distribution in rat cerebral cortex. Soc. Neurosci. Abstr. 7: 502.

Lord, J. A., A. A. Waterfield, J. Hughes, and H. E. Kosterlitz (1977) Multiple opiate receptors. Nature 267: 495-499.

Meibach, R. C., S. Maayani, and J. P. Green (1980) Characterization and radioautography of $\left[{ }^{3} \mathrm{H}\right] \mathrm{LSD}$ binding by rat brain slices in vitro: The effect of 5-hydroxytryptamine. Eur. J. Pharmacol. 67: 371-382.

Moon Edley, S., M. Herkenham, and C. B. Pert (1981) Variations in the opiate receptor distribution in the mammalian striatum. Soc. Neurosci. Abstr. 7: 502.

Mugnaini, E., W. B. Warr, and K. K. Osen (1980) Distribution and light microscopic features of granule cells in the cochlear nuclei of cat, rat, and mouse. J. Comp. Neurol. 191: 581-606.

Munson, P. J., and D. Rodbard (1981) Statistical comparison of two assay methods. In Quality Control in Clinical Endocrinology, D. W. Wilson, S. J. Gaskell, and K. W. Kemp, eds., pp. 89-98, Alpha Omega Publishing, Ltd., Cardiff, Wales, UK.
Palacios, J. M., D. L. Niehoff, and M. J. Kuhar (1981a) Receptor autoradiography with tritium-sensitive film: Potential for computerized densitometry. Neurosci. Lett. 25: 101-105.

Palacios, J. M., D. L. Niehoff, and M. J. Kuhar (1981b) $\left[{ }^{3} \mathrm{H}\right]$ Spiperone binding sites in brain: Autoradiographic localization of multiple receptors. Brain Res. 213: 277-289.

Pasternak, G. W., R. H. Wilson, and S. H. Snyder (1975) Differential effects of protein-modifying reagents on receptor binding of opiate agonist and antagonists. Mol. Pharmacol. 11: 340-351.

Pearse, A. G. E. (1980) Histochemistry: Theoretical and Applied. Vol. I: Preparatory and Optical Technology, Ed. 4, Churchill Livingstone, New York.

Pearson, J., L. Brandeis, E. Simon, and J. Hillar (1980) Radioautography of binding of tritiated diprenorphine to opiate receptors in the rat. Life Sci. 26: 1047-1052.

Pellegrino, L. J., and A. J. Cushman (1967) A Stereotaxic Atlas of the Rat Brain, Appleton-Century-Crofts, New York.

Penney, J. B., Jr., H. S. Pan, A. B. Young, K. A. Frey, and G W. Dauth (1981) Quantitative autoradiography of $\left[{ }^{3} \mathrm{H}\right]$ muscimol binding in rat brain. Science 214: 1036-1038.

Pert, A. (1978) Central sites involved in opiate actions. In The Bases of Addiction, J. Fishman, ed., pp. 299-332, Dahlem Konferenzen, Berlin.

Pert, C. B. (1981) Brain distribution of Type 1 and Type 2 opiate receptors: What does it tell us? In Neurosciences and Brain Peptides, J. B. Martine, S. Reichlin, and K. L. Bick, eds., pp. 117-131, Raven Press, New York.

Pert, C. B., and B. Garland (1978) The mechanism of opiate agonist and antagonist action. In Receptors and Hormone Action, Vol. III, B. W. O'Malley and L. Brinbaumer, eds., pp. 535-551, Academic Press, New York.

Pert, C. B., and M. Herkenham (1981) From receptors to brain circuitry. In Biochemistry of Taste and Olfaction, R. Cagan, ed., pp. 511-522, Academic Press, New York.

Pert, C. B., and S. H. Snyder (1973) Properties of opiate receptor binding in rat brain. Proc. Natl. Acad. Sci. U. S. A. 70: 2243-2247.

Pert, C. B., M. J. Kuhar, and S. H. Snyder (1975) Autoradiographic localization of the opiate receptor in rat brain. Life Sci. 16: 1849-1854.

Pert, C. B., M. J. Kuhar, and S. H. Snyder (1976a) Opiate receptor: Autoradiographic localization in rat brain. Proc. Natl. Acad. Sci. U. S. A. 73: 3729-3733.

Pert, C. B., A. Pert, J. -K. Chang, and B. T. W. Fong (1976b) [D-Ala ${ }^{2}$-Met-enkephalinamide. A potent, long-lasting synthetic pentapeptide analgesic. Science 194: 330-332.

Pert, C. B., D. P. Taylor, A. Pert, M. A. Herkenham, and J. L. Kent (1980) Biochemical and autoradiographic evidence for Type 1 and Type 2 opiate receptors. In Neural Peptides and Neuronal Communication, E. Costa and M. Trabucchi, eds., pp. 581-589, Raven Press, New York.

Pfaff, D. W. (1968) Autoradiographic localization of radioactivity in rat brain after injection of tritiated sex hormones. Science 161: 1355-1356.

Polz-Tejera, G., J. Schmidt, and H. J. Karten (1975) Autoradiographic localization of $\alpha$-bungarotoxin-binding sites in the central nervous system. Nature 258: 349-351.

Quirion, R., R. P. Hammer, Jr., M. Herkenham, and C. B. Pert (1981) The phencyclidine (angel dust)/ $\sigma$ "opiate" receptor: Its visualization by tritium-sensitive film. Proc. Natl. Acad. Sci. U. S. A. 78: 5881-5885.

Rainbow, T. C., W. V. Bleisch, A. Biegon, and B. S. McEwen (1982) Quantitative densitometry of neurotransmitter receptors. J. Neurosci. Methods 5: 127-138.

Rogers, A. W. (1979) Techniques of Autoradiography, Elsevier/ North-Holland, New York.

Sar, M., W. E. Stumpf, R. J. Miller, K. -J. Chang, and P. 
Cuatrecasas (1978) Immunohistochemical localization of enkephalin in rat brain and spinal cord. J. Comp. Neurol. 182: $17-38$.

Stumpf, W. E. (1968) Estradiol-concentrating neurons: Topography in the hypothalamus by dry-mount autoradiography. Science 162: 1001-1003.

Stumpf, W. E., and L. G. Roth (1966) High resolution autoradiography with dry mounted freeze dried frozen sections. Comparative study of six methods using two diffusible compounds $\left[{ }^{3} \mathrm{H}\right]$-estradiol and $\left[{ }^{3} \mathrm{H}\right]$-mesobilimubinogen. J. Histochem. Cytochem. 14: 274-286.

Uhl, G. R., R. R. Goodman, M. J. Kuhar, S. R. Childers, and S. $H$. Snyder (1979) Immunohistochemical mapping of enkephalin containing cell bodies, fibers and nerve terminals in the brain stem of the rat. Brain Res. 166: 75-94.

Unnerstall, J. R., D. L. Niehoff, M. J. Kuhar, and J. M. Palacios (1982) Quantitative receptor autoradiography using $\left[{ }^{3} \mathrm{H}\right]-\mathrm{Ul}-$ trofilm: Application to multiple benzodiazepine receptors. J. Neurosci. Methods, in press.

Wamsley, J. K., M. Zarbin, N. Birdsall, and M. J. Kuhar (1980)
Muscarinic cholinergic receptors: Autoradiographic localization of high and low affinity agonist binding sites. Brain Res. 200: 1-12.

Willis, W. D., and R. E. Coggeshall (1978) Sensory Mechanisms of the Spinal Cord, Plenum, New York.

Wilson, R., M. Rogers, C. B. Pert and S. H. Snyder (1975) A homologous series of analgesics: Correlation of receptor binding with analgesic potency. J. Med. Chem. 18: 240-245.

Wise, S. P., and M. Herkenham (1982) Opiate receptor distribution in the cerebral cortex of the rhesus monkey. Science, in press.

Young, W. S., III, and M. J. Kuhar (1979) A new method for receptor autoradiography: $\left[{ }^{3} \mathrm{H}\right]$ Opioid receptors in rat brain. Brain Res. 179: 255-270.

Young, W. S., III, and M. J. Kuhar (1980) Radiohistochemical localization of benzodiazepine receptors in rat brain. J. Pharmacol. Exp. Ther. 212: 337-346.

Zeman, W., and J. R. M. Innes (1963) Craigie's Neuroanatomy of the Rat, Academic Press, New York. 